\title{
Global Financial Education: A Strategy to Advance Microfinance
}

\author{
Fredrick Onyango Ogola \\ Academic Director- MBA programs Director- Institute of Strategy and Competitiveness \\ Strathmore University Business School \\ Professor Josep F. Mària SJ \\ Associate Professor, ESADE Business School, Av. De la Torre Blanca, 59 \\ E-08172 Sant Cugat del Valles, Barcelona, Spain
}

\begin{abstract}
The research was financed by ESADE Business School (Sponsoring the researcher in his PhD studies) Abstract

There is growing evidence that microfinance institutions (MFIs) have substantial benefits for consumers, especially women in financial inclusion. Several attempts have been made to explain why MFIs have not been able to bridge to financial inclusion. Prior research has addressed the reasons why globally; two-thirds of adults do not have an account. However, little is known about the role of financial education that leads to financial literacy especially regarding the method, mode, form and subject. This study proposes Global Financial Education (GFE)that would lead to financial literacy among MFI clients in order to empower them to select appropriate MFIs, MFI products and services, right channels for greater financial inclusion. We propose a practical mode of implementing GFE. This is likely to propel financial inclusion as opposed to merely access to credit through informal financial institutions where clients are caught in a vicious cycle of poverty, unable to transition to middle class status.
\end{abstract}

Keywords: Financial Inclusion; Financial Literacy; Global Financial Education; Micro-Financial Institutions; DOI: $10.7176 / J P I D / 55-05$

Publication date:August $31^{\text {st }} 2020$

\section{Introduction}

Microfinance industry has grown sustainably over the past two decades with the goal of helping reduce if not eradicate poverty (UFA2020). From the emergence of micro-credit reaching large numbers of people to advancement from microcredit into microfinance then into the concept of building entire financial systems that serve the poor and low-income populations - financial systems that are "inclusive (Helms, Littlefield, \& Porteous, 2015)." This new, more ambitious and complex vision captured the attention of governments, international financial institutions, philanthropists, social investors, mainstream bankers, and even some royalty and celebrities (Helms et al., 2015). Consultative Group to Assist the Poor (CGAP) identified over 750 million savings and loan accounts in institutions that cater to the lower economic strata; $74 \%$ of these were in state-owned savings, development, and postal banks. Second study by Peachy and Roe identified over 1.4 billion accessible (low average balance, low-cost) accounts in developing and transition economies (Helms et al., 2015). We now understand that poor and low-income people can fruitfully use and pay for a range of financial services. Financial services for the poor are delivered by banks and other retail organizations as well as NGOs. A few years ago, CGAP research identified well over 750 million savings and loan accounts in institutions that cater to the lower economic strata; 74 percent of these were in state-owned savings, development, and postal banks. 1 A second study by Peachy and Roe identified over 1.4 billion accessible (low average balance, low-cost) accounts in developing and transition economies (Helms et al., 2015).

In 2015 the World Bank Group and public and private sector partners adopted measurable commitments to achieve Universal Financial Access by 2020 (UFA2020) and help promote financial inclusion. These were through creating a regulatory environment to enable access to transaction accounts, expanding access points, improving financial capability, driving scale and viability through high-volume government programs, such as social transfers, into those transaction accounts, focusing on reaching disadvantaged populations, such as women and rural producers, encouraging use of financial services, to move from access to finance to account use working through critical value chains in priority countries to digitize payments, and creating access to other financial services such as savings, insurance, and credit. Yet we are now in 2020 and that promise has not yet been delivered. The situation remains like it was in the late 1990s when Microfinance Institutions (MFIs) and programs have not been able to deliver that promise (Morduch, 1998; 1999). This suggests that microfinance revolution as it is today may not be enough for the task and additional innovations are required. Adults in all income groups around the world use a variety of financial services, ranging from digital payments and savings accounts to loans and insurance. Many low-income adults, however, rely largely on informal financial services -2 billion adults worldwide, or 38 percent, reported not having an account at a formal institution in 2014, according to Global Findex data (Asli Demirguc-Kunt, 2017). This is despite the improvements in financial access brought about by MFIs and Mobile 
Money; two-thirds of the world's adults still do not have a basic bank account. Access to a bank account is only one dimension of financial inclusion, but it is a critical one. A basic bank account is the entry point that allows customers to save money outside the household, make loan or premium payments, or transfer funds within their country or across borders. More than 80 percept of households have bank accounts in high-income countries, compared to well below 20 percent in low-income countries.

MFI practitioners around the world are actively pursuing innovations that can help augment their contribution to the welfare of their clients. A strong trend in these innovations is the combination of microfinance with other non-financial services, including business training or financial education (Dunford, 2002). This trend has caused tension in the development finance community with questions about whether lenders should specialize in financial services only, or should integrate non-financial services into their program (MkNelly, Watetip et al. 1996). Even more worrying could be the fact that MIFs that integrate financial services and other non-financial services, especially financial education could only be doing it for their selfish benefits, that is, customer retention and loyalty. This forces them to carry out financial education so selectively without even empowering their clients or potential clients with the knowledge they need to make informed decisions not just on the available financial products and services on offer but also which MFIs are suitable for them and how they can build their portfolio in order to transition to Middle class from vicious cycle of poverty of low income status. Since key items to poverty alleviation are capital, knowledge and opportunity (Khumawala, 2009), only offering capital (micro-credit) but no or poor knowledge (selective education) does not enable the poor use well the capital and the opportunity before them to come out of cycle of poverty.

In fact, since more than one MFIs exist in a country; micro-finance clients also need to be educated about the different financial products that are on offer by the many MFIs. This calls for financial education ("microfinliteracy") that enables the microfinance clients or potential clients to know at least essential elements of every of MFIs and their products and services in a market rather than know only everything of one particular MFI or MFI product. The recognition by the World Bank that awareness and financial literacy is one of the catalytic pillars toward financial inclusion affirms this position (Bank, 2018). The maxim should be that "micro-clients" get be micro-finliterate before consuming micro-finance in order be successful micro-entrepreneurs.

This study postulates that such financial education leading to microfinliteracy, which we call Global Financial Education (GFE), has not yet been given proper attention. This is partly the reason why the World Bank goal has not been delivered in 2020 that has even been disrupted by covid19 pandemic. This is because MFIs still tend to only provide Selective Financial Education (SFE). With SFE, clients or potential clients are only educated based on the products and services provided by a particular MFI. In fact, according to Kazmin (2010), the regulatory backlash has highlighted the risk of pushing credit to the poorly educated borrowers or uncertain financial literacy. Consequently, SFE binds these people to the respective MFIs and thus trapped in a never-ending cycle of debt hence unable to attain financial stability. This stands in strict contrast to the essential goal of Microfinance that was promoted by the Grameen Bank as the first MFI in the world and the institutions that followed, that is, to enable the poor to escape from the vicious cycle of poverty. Frisancho, Karlan \& Valdivia (2008) reported that supply of MFI products and services is greater than demand due to several reasons, among them being low financial literacy that does not enable the poor perceive the value of micro-credit. This could be partly because currently, MFIs offer financial literacy program only to their clients or in condition that one has accepted to be a client. Therefore, there is a need for financial education that offers financial education irrespective of whether the participants needs micro-credit or not. It is envisaged that this financial education program based on GFE model could create demand as the poor will get financial literacy uncondionally (whether they take credit or not from a particular MFI).

GFE is a mechanism, which allows the poor, who are operating closer at the margin than anybody else, to receive information about their options in Microfinance. It empowers them to make smart choices and to select the most appropriate products at the right time from those MFIs that offer a portfolio of products and services which best suits their needs. This is what Ogola (2011) refers as expansion of financial freedom in his framework for analysing the social responsibility of financial institutions in developing countries. GFE, therefore, becomes important tool in aiding this financial freedom.

The structure of this article is as follows. First, we present the concept of microfinance, its origin and underlying purpose. Second, we highlight the importance of financial education as an essential component of Microfinance Institutions (MFIs). This is followed by clarifying terms such as Financial Education (FE) and Financial Literacy (FL). Then we present previous literature leading to the knowledge gap. This leads to introducing of Global Financial Education as a novel concept and its urgent need. Next, the research questions are formulated and an appropriate method to respond to the research questions are presented. This is followed by the analysis and presentation of the findings. The article finally concludes giving the theoretical and managerial implications, limitations and recommendations for future research into GFE. 


\section{An Education in Microfinance}

To enable the transition from Bottom Of Pyramid (BOP) to financial (economic) stability, there is a need for a mechanism, which enables the poor to identify the "black sheep" in the finance industry. As more and more MFIs are being founded, the poor need to be able to stay away from those MFIs, which have disadvantageous offerings for them and select only those microfinance-products and MFIs, which suit them, their needs and their abilities and match their opportunities. This can be achieved, the current study proposes, by enhancing the poor's financial literacy through GFE. In fact many of them that emerged pre-covid19 pandemic are now pushing their clients to forget about "brick and mortar" they mean banks and fully embrace digital solutions which for them is more microcredit than savings yet we know that Financial inclusion means that adults have access to and can use a range of appropriate financial services. At its most basic level, formal financial inclusion starts with having a deposit or transaction account at a bank or other financial institution or through a mobile money service provider. The account can be used to make and receive payments and to store or save money. Financial inclusion also involves access to appropriate credit from formal financial institutions, as well as the use of insurance products that allow people to better manage financial risks such as crop damage (Asli Demirguc-Kunt, 2017). In fact, empirical evidence shows that financial inclusion allows people to make many everyday financial transactions more efficiently and safely. Use of the formal financial system also expands their investment and financial risk-management options. This is especially relevant for people living in the poorest households (Asli Demirguc-Kunt, 2017). This is the kind of knowledge or aware that the poor needs to get through non-selective financial education by financial institutions. In that regard, we first differentiate the terms Financial Education and Financial Literacy. We then introduce the novel concept of Global Financial Education (GFE) and finally define and explain the two main research questions of this study.

\subsection{Financial Education vs. Financial Literacy}

The current developments in the finance sector and the financial crisis have demonstrated how important it is for consumers of all backgrounds to understand the products and their options in the field of finance. As consumers gain access to more and more different and increasingly complex financial products, they have to be able to gain much knowledge about existing financial products to safeguard them against exploitation and also enable make better use their opportunities (Jappelli, 2009) and mitigate against risks (Miller, Godfrey, Levesque, \& Stark, 2009). Financial Literacy is the ability to understand financial concepts and products and to appreciate risks and opportunities in order to make informed choices and take effective actions (Miller, Godfrey, Levesque, \& Stark, 2009). Financial Education on the other hand, describes the process of teaching knowledge, skills and actions that enable individual consumers to make better financial choices. Financial education is therefore a process that results in Financial Literacy (Cohen, Stack, \& McGuiness, 2004).

\subsection{Why Financial Education for the Poor?}

Financial literacy differs widely across demographic groups. Especially members of less educated, poor households tend to possess rather limited financial skills (Jappelli, 2009). There is evidence that on overall, levels of financial literacy are particularly low in developing countries where many individuals are poor and lack basic general education (Miller, Godfrey, Levesque, \& Stark, 2009). However, it in these countries that financial literacy may have greater impact against poverty and in expanding financial inclusion

The poor share the same goals as the non-poor. They aim to reach financial stability in order to protect themselves and their families in the long term. However, what differentiates them is the lack of money and that many of them live in unstable, unpredictable environments (Sebstad \& Cohen, 2003). They operate at the margin every day hence they have financial instability. In fact, they have so limited belongings hence their margin of error is almost nill. For this reason not being able to make smart choices with regard to selecting appropriate financial institutions and products and services can have severe impacts on the poor and low-income earners. Therefore some form of financial education is critical for these groups.

In addition, it needs to be highlighted that, in recent years, more and more MFIs and with that more and more MFI products and services have entered and are entering the market. By 2010, the Microfinance Information Exchange lists e.g. as many as 149 MFIs in India, 110 MFIs in the Philippines and 101 MFIs in Russia (Microfinance Information Exchange, 2010 ). Thus, micro-finance clients face numerous choices, which are increasing every day. However choosing the best financial product and services and MFI among such a great number of choices requires a lot of knowledge and skill. The chances that the poor would make the right choices could be enhanced through financially literacy, that is, being able to calculate costs and benefits as well as weigh alternatives, an ability seldom possessed by the poor (Sebstad \& Cohen, 2003). They also need to be educated as entrepreneurs which MFI products gives them lower cost of capital, better cash flow management and liquidity hence much these with their immediate business needs when seeking for credit solutions.

In fact, from an MFIs perspective an increasing customer base and a high customer loyalty are among the highest priority. First, since the loans they distribute are usually small in value, the operating costs of MFIs are 
rather high. Furthermore, the more customers an MFI has, the more it can benefit from economies of scale. Thus, it will be the major aim of an MFI to rapidly increase its customer base as well as to increase the loyalty of its customers in order to become financially sustainable and profitable in the long term. Therefore, MFIs are very much likely to only educate their clients selectively about the products they offer in order to increase their customer base and maintain customer loyalty without referring to some potential clients and existing clients to other MFIs that could be more appropriate for the respective clients.

\section{The concept of Global Financial Education}

One effective mechanism that would enable micro-finance clients or/and potential clients become financial literates, the current study proposes, is Global Financial Education (GFE). The current study assumes that MFIs are still carrying out Selective Financial education. The underlying idea is that the poor need to be provided with a form of financial education that gives them a relevant, sufficient and comprehensive understanding of the options and choices they have with regard to MFIs and their financial products and services.

The term Global refers to the concept that some mechanism needs to be developed which educates the poor in a neutral and comprehensive manner, providing them with a holistic understanding of the scope of the different financial products and institutions they can take advantage of.

The term Global Financial Education rather than Global Microfinance Education has been selected because not only do micro-finance clients need to possess abilities to judge amongst micro-finance products, they need to have an understanding about the subject of Finance in general in order to select the appropriate MFI or Financial Institution for them in the first place. In addition to that, it is also likely that MFIs exit the market at some point (because of insolvency etc.). In this case, micro-finance clients need to be able to select among the other MFIs and Financial institutions which are still existing in the market. Furthermore, it is likely that, at some point with regard to the goal of microfinance, a micro-finance client might have accumulated enough earnings so that they escape poverty. At this stage, it is likely that they do not need the service of an MFI but a formal Financial Institution. This will transition the poor and low income earners into financial inclusion hence escape the vicious cycle of poverty. With full financial inclusion there will be both credit but also savings and investments due to bank accounts. The transition that could be propelled by proper financial education is key since in spite of the improvements in financial access brought about by MFIs and Mobile Money, two-thirds of the world's adults still do not have a basic bank account. Access to a bank account is only one dimension of financial inclusion, but it is a critical one. A basic bank account is the entry point that allows customers to save money outside the household, make loan or premium payments, or transfer funds within their country or across borders and be able to invest. Moreover, Savings drive more development than credit since investments equal savings, which is only possible under financial inclusion not just access to credit.

\subsection{The Impact of Global Financial Education}

The impact of Global Financial Education is illustrated in Figure 1. Suppose there is a micro-client who falls in the group X, those who have not received GFE. They are customers of MFI 1 in the first place and they only possess a selective financial education provided by their respective MFI, that is, they only know about products from MFI 1. Eventually MFI 1 exits the market and micro-client X needs to identify a new MFI or a mainstream Financial Institution for their needs. In this example, suppose that MFI 2 would be the best option for them because it had a product portfolio, which was most likely to address the needs of client X comprehensively. Also suppose that MFI 3 would be the worst option for our respective micro-client X because its product offering would not be able to fulfil their needs. Further, suppose that there were a mainstream FI, which would be a better choice than MFI 3 for client X but a worse choice than MFI 2 in terms of its ability to fulfil the needs of client X. (Insert figure 1 about here)

Since client $\mathrm{X}$ is only selectively educated they are not able to judge among the different offerings of the various MFIs and Financial Institutions within their country. Therefore, $\mathrm{X}$ is most likely to choose the next-best option, which would be MFI 3 in this example. MFI 3, however, is not the best option for them but the worst and in the long term client $X$ will not have many benefits from this relationship. If client $X$ had had GFE they would have understood that MFI 3 had the product portfolio, which would fulfil their needs in the worst possible manner, that FI would be a semi-optimal choice and that MFI 2 would be the best choice as it offered the best product portfolio for their interests.

If micro-clients are able to select the products that suit them, MFIs will also profit in the long term. This is because when a client only depends on one or two products from one or two MFIs their commitment to the institution(s) is likely to be very high. Thus, repayment rates are also likely to increase as clients who have a better overview of the few financial products they are using are more conscious about the respective product features and can record positive results faster and more easily. As MFIs usually have higher transaction costs (see chapter 2.4.1), they need to decrease default rates. If they only attract highly committed clients, who have a good understanding of the product they are using, a higher commitment to the MFI and who are more likely to repay 
their loans MFIs can also benefit in that respect to a great extent.

\subsection{The Wider Impact of Global Financial Education}

Financial Literacy is not only important for individuals and individual institutions; it can also have deep impacts on the respective community or country economy. If micro-clients are able to select appropriate MFIs ad their products and services, positive multiplier effects are very much likely to result within their community on a longterm perspective. Following Woller and Parsons, if there is an exogenous change in the environment (e.g. caused by a change in investment, government spending, etc.), the term income multiplier refers to the total change in income earned by all workers in the local economy (Woller \& Parsons, 2002).

This means, that if a person is able to select appropriately MFIs and financial products and services, which enables them to create a sustainable microenterprise, this person could contribute to the local economy in various ways. First, person A might buy raw materials for their business, thus creating income for an additional person B of the local economy, who provides these raw materials. In addition, person B might then spend their profits made through the purchase from A on some service or product within the local economy, creating more demand which might then result in a new workplace for $\mathrm{C}$ who will eventually also have expenditures within the local community and so on. Consequently, a certain amount of the expenditures is being saved or spent on other communities. Such expenditures to other communities or savings are referred to as leakage (Woller \& Parsons, 2002). This process continues until the community is saturated and no additional money for spending is being generated.

Thus, if micro-clients are able to select proper finance-products that enable them to create sustainable microbusinesses, the income-multiplier effects are very much likely to result in a positive development of the local community, that is, the micro-economy. If spill-over-effects occur, that is, spending within other local communities nearby or leakage, these communities are positively affected as well.

(insert figure 2 about here)

Finally, the overall area or country could benefit to a great extent, as their overall economy is likely to develop. If the overall local economy is developing and more and more legal microenterprises exist and as profits of these enterprises are increasing, private expenditures are increasing as well. Therefore taxes, which are paid to the state, are increasing too. Also, private expenditures for health services are likely to increase which decreases the need for public health expenditures by the state as the overall health of the population increases. Finally, if the state has more tax income the overall welfare is increasing as it can then be invested into education, infrastructure and much more. Figure 2 illustrates these wider impacts of Microfinance enhanced through GFE.

Furthermore, following Michael E. Porter's model of "The 5 Forces that shape Strategy" Global Financial Education has the power to increase the bargaining power of customers. In the model, Porter describes five forces that define the competitiveness in an industry and affect the profitability of companies. The five forces described in his model are: bargaining power of suppliers, bargaining power of customers, rivalry among existing competitions, threat of substitutes, and the threat of new entrants (Porter, 1979). GFE can influence the bargaining power of customers. Financially literate customers would be able to select the most advantageous MFIs for them. This would then pose a threat on MFIs with disadvantageous offerings because their customer base would decrease.

In that regard, choosing the right financial products on an individual basis may result in a positive development of the local economy, the local economies nearby and finally the overall economy of a country caused by positive income-multiplier effects. Furthermore, GFE could also affect the Microfinance industry of a country. As the power of buyers increases, buyers are more and more able to select appropriate MFIs for themselves and the customer bases of MFIs with rather inappropriate offerings diminish.

\subsection{Formulation of RQ1a, RQ1b and RQ2}

The three research questions RQ1a, RQ1b and RQ2 that shall be investigated in this study are now developed and explained. Key to the formulation of these questions are the following two underlying postulations:

$>\quad$ Global Financial Education is important

$>\quad$ A comprehensive Global Financial Education not yet exist

The first postulation posits that Global Financial Education is important and is based on the fact that globally financially educated micro-clients are able to escape the vicious cycle of poverty by making smart and reasonable choices.

As more and more MFIs are commercializing and more and more MFIs are entering the market which do not follow a social mission but solely focus on profit (Greeley, 2006) and their investors' interests (Nair, 2010), the poor need to be enabled to select carefully the proper product or products from the proper institution or institutions. This will be possible through Global Financial Education. In addition, microfinance clients that have received GFE are more likely to select only a few but very appropriate products from only one or a few MFIs rather than loosing themselves in numerous different loan-products from numerous different institutions which could render them less efficient as entrepreneurs.

The second underlying assumption, a comprehensive Global Financial Education does not yet exist, is based 
on the fact that, whereas some MFIs teach entrepreneurial skills (Khandker, 2005), it is expected that the findings of this study support that none of MFIs provide, GFE SFE. Thus it is likely that MFIs do not provide their clients with an overall picture of the choices, which exist for them in the market but try to bind them to their institution by only educating them about what they have to offer and maybe even using persuasive tactics to attract more customers. It is worth noting that RQ2 will build on the findings of RQ1a and RQ1b.

The first research question was focused on investigating whether there is any MFI that provides GFE, therefore we ask;

- $\quad$ RQ1a: Are MFIs providing Global Financial Education to their clients or potential clients?

Earlier the study illustrated that, whereas some MFIs provide a kind of "Entrepreneurial Education", the concept of "GFE" is a novel concept in the field of microfinance. However, there is an urgent need for such an education for the poor and, in particular, for micro-clients.

It has been discovered that MFIs do provide education for their clients. However, Global Financial Education is a novel concept. In that regard, it is most unlikely that there is evidence to support the present existence of a comprehensive Global Financial Education. This is in line with the second underlying assumption that was explained in part 3.4, namely that Global Financial Education does not exist. This answers RQ1a. This takes us to RQ1b;

- $\quad$ RQ1b: What Types of Financial Education are currently provided by MFIs?

This part has classified the forms and kinds of education, which were found to exist in the Microfinance sector. Not only was the subject of the education to be classified, it was also to be differentiated as well in what manner the respective education was being provided. It was expected that evidence for entrepreneurial education as well as for an education in health or social empowerment would be found. This leads to RQ2:

- RQ2: Can Global Financial Education have a better impact than selective education?

This part of the study has concentrated on possible impacts that would result from the introduction of GFE. RQ1a was expected to illustrate the existing types of financial education while RQ1b is expected to give insights into the limitations of the specific classifications. Therefore, findings of RQ2 are expected to contrast the possible impacts and advantages micro-clients and MFIs compared to the impacts of the existing SFE.

In brief, chapter 3 has introduced the term Global Financial Education and has justified the introduction of this concept for the poor. Furthermore, possible closer and wider impacts of Global Financial Education have been illustrated and the three research questions of the following study have been developed and their expected outcomes have been described.

\section{Research Design}

\subsection{Sample}

As reported earlier, in 2010, the number of MFIs listed by the Microfinance Information Exchange is around1800 and some estimation have listed numbers much higher than that. Since it is nearly impossible to study all of these MFIs, the sample that was used for this study is the list of the Top 50 MFIs from the Forbes Magazine. The Magazine had ranked the Top 50 MFIs in 2007 according to four categories: scale, efficiency, risk and return by evaluating data from over 640 MFIs provided by the Microfinance Information Exchange (Swibel, 2007). The two institutions are very well known; on the one hand, the Forbes Magazine is a renowned American business magazine with publications in many different countries of the world, on the other hand, the Microfinance Information Exchange is known to provide comprehensive data in Microfinance Sector.

The Top 50 MFIs of the sample, which have been used for this study (Table 1), are from 24 different countries and represent a very good distribution over four different continents with 10 of them being from Africa, 16 from Asia, 12 from Europe and 13 from South America. With regards to the country of origin, the majority of MFIs are from India (7), Bangladesh (7) and Bosnia Herzegovina (5). In the overall ranking, ASA from Bangladesh is on the top followed by Badhan (Society and NBFC) from India and Banco de Nordeste from Brazil on rank two and three. In terms of scale, that is the gross loan portfolio, the Grameen Bank of Bangladesh ranks first. The Microcredit Foundation of India is ranked most efficient. The first place of portfolio risk is shared by 28 MFIs and as most profitable are Banco Compartamos, S.A., Institutción de Banca Múltiple of Mexico. Also, rank 23 of the overall ranking is shared by Caja Municipal de Ahorro y Crédito de Trujillo and the Sharada's Women's Association for Weaker Section which lead to a number of 51 MFIs in the overall sample.

It has to be highlighted that the ranking does not contain any measure that evaluates the social benefits of the respective MFIs (Swibel, 2007). Still, it was considered to provide a relevant sample for this study as it listed those 51 MFIs in the world, which are the most efficient from a financial perspective.

Naturally, for a bank to exist and be sustainable in the long term, it is a relevant condition to be financially sustainable. In the Microfinance sector being financially sustainable is even more relevant and difficult to achieve as loans are usually very small and transaction costs are high. Thus, the Top 51 MFIs from this sample can be seen as role models because they have functioning financial structures and are the ones that shape the emerging Microfinance-industry. These MFIs, being considered among the most successful in the industry are most likely 
to have implemented best practices and to act as first movers in the industry. In addition, the sample consists of MFIs from many different countries on various continents, which is expected to further benefit the predictability of the existence of a GFE. Therefore, these 51 MFIs are studied in order to investigate whether GFE is being provided to give valuable conclusions for the entire industry.

\subsection{Analysis}

Now that the sample has been defined, there are several methods, which can be used to investigate whether a GFE exists, and what could be its impact as compared to SFE.

To answer RQ1a and RQ1b, conducting a web-based research on the websites of the 51 MFIs of the sample has been selected as a first method.

As a second step, selected interviews via phone or Email with industry insiders and people who work for or have related with these MFIs was undertaken to enrich and better interpret the findings of the web-based research.

First, the Grameen Creative Lab was contacted. This organization, which is situated in Wiesbaden, Germany, is a joint venture of he Yunus Center of Bangladesh and Circ Responsibility of Wiesbaden, Germany. The aim of this joint venture is to accelerate social business in order to alleviate poverty. Because of the nature of this Creative Lab where innovation in social business is fostered and the close relationships to the Grameen Bank as the most prominent role model in the Microfinance Industry, this Lab is considered a great source of information.

Second, Mr. Karl Strempel was contacted to serve as a second interview partner. He has worked for Muhammad Yunus and the Grameen Bank for some years. During his work for the Grameen Bank, he was able to learn about the work of the bank in all different levels. He visited and worked in the local villages and the local branches as well as for Yunus directly, serving as one of his country managers for Grameen. He was lastly placed in Haiti where he worked as country manager, supporting the reconstruction through the foundation of social businesses of all kinds after the earthquake in 2010. Currently he works as a consultant for Bain \& Company. He is considered as an important interview partner because he had gained deep insights into Grameen in various countries and had worked at different levels within the company. Moreover, he is a strategy consultant and is expected to give relevant insights into the practical and strategic implementation of a GFE.

\subsubsection{Analysis of the web-based research with regard to RQ1a and RQ1b}

Table 2 illustrates the overall results of the web-based research. The final sample of this study consisted of 48 MFIs. The sample decreased because the websites of three MFIs (all three from Eastern Europe) could not be found or accessed. In addition, two institutions shared rank 23 of the TOP 50 MFIs, which lead to a final sample of 48 MFIs. Furthermore, it shall be noted that, two of the MFIs from the Forbes ranking of 2007 had changed their name in the meantime because another institution acquired them.

Most of the websites were available in English or Spanish, both languages of which the authors are proficient. However, all websites, which were not available in English, Spanish or German, were translated with the Google Translate Bar, which is integrated in the browser Google Chrome. The Google Translate bar allows users to translate a website into a different language. Although the grammar of the translated text was not always perfectly correct, it was considered to give an understanding of the website, valid enough to judge whether the MFI offers education or not and in what form this education is being provided. The exact information of all websites of the Top 48 MFIs of the Forbes Ranking, which were investigated in this study, is listed in Appendix 2.

Of the total sample, evidence found that 37\% (18) MFIs offered some sort of active education program for their micro-clients.

Figure $4 \mathrm{a}$ and $4 \mathrm{~b}$ contrast the regional distribution of the overall sample with the regional distribution of those MFIs that offer education in general for their clients. Whereas the overall sample is very much balanced in terms of its regional distribution, with a smallest share of $19 \%$ of the studied MFIs being based in Europe and a biggest share of $33 \%$ of the MFIs based in Asia (Figure 3a), the dispersion of educational offerings for micro-clients is highly skewed towards the Asian continent. Figure 3b illustrates that $67 \%$ (12) of the 18 MFIs, which offer active education for their clients, are from Asia. Second it does demonstrate that 22\% (4) of the educational offers for micro-clients are provided by South American MFIs. Finally it illustrates that only $5 \%$ and $6 \%$ of education offered by MFIs are being provided by MFIs from Africa and Europe respectively.

It has to be noted that whenever an MFI was recorded to offer education, this refers to active methods and involvement of the clients in education programs as opposed to including clients into passive methods that might also improve their knowledge or consciousness about various topics.

Active methods are mechanisms that actively involve customers into regular educational activities with the MFI, for example training seminars, or group workshops. An example for a passive mechanism, on the other hand, would be the 16 Decisions of the Grameen Bank (see chapter 2.3.1, appendix 1). Here, the micro-clients commit to behave according to the 16 rules that were appointed by the bank in order to become clients of the institution. These rules incorporate educational topics, which are likely to raise the consciousness, and awareness of the microclients on certain issues, such as improving sanitary standards or improving the rights of women. However, Grameen clients are not being actively involved into regular educational activities such as training sessions because 
Grameen believes that the power to engage in and benefit from entrepreneurial activities is inherent in every person (Yunus, 1997).

Furthermore the active education, which has been reported in table 2, refers to direct education as opposed to indirect education. Direct education consist of the direct communication of the respective educational topic which are taught, for instance, in a training session which is called "how to create a cash-flow-analysis". Indirect education could, for instance, consist of weekly group meetings where people would, for example, see how well the businesses of their peers functioned and therefore felt the pressure or became more conscious to create a functioning business.

To gain a better overview and a more detailed understanding of the different subjects of education that are being provided by MFIs, the various subjects which were found to be provided by the studied MFIs were classified into six different categories:

\section{- $\quad$ Financial Education}

(Setting up a bank account, taking a loan, importance of saving etc.)

- $\quad$ Entrepreneurial Education

(Creating a business plan, cash flow analysis, marketing strategies etc.)

- Social Education

(Awareness of human rights, female empowerment, renewable energies etc.)

- Health Education

(HIV Prevention, importance of sanitary standards etc.)

- $\quad$ School Education

(Primary, Graduate and Post-graduate education)

As Table 2 and Figure 5 illustrate, some MFIs offer more than one type of education at the same time. Table 2 shows in detail which types of education are being offered by which MFI. Figure 4 illustrates graphically the proportion of the different subjects of education, which are offered by the 18 MFIs. It becomes clear that Entrepreneurial Education is the most common subject, which is offered by the MFIs $(83 \%$ (15) of the reviewed MFIs). The second most common subject of education is Health Education, which is offered by $44 \%$ (8) of the MFIs that offer educational programs. School and Social education are each offered by 28\% (5) of the MFIs that were studied. Finally, evidence of active Financial Education was only found among 22\% or 4 of the 18 MFIs, which were found to offer active education for their clients.

Active education is offered by the MFIs through different activities. The most common forms of education were either group workshops or training. Usually those MFIs, which offer group lending, such as the Grameen bank did in earlier years (see chapter 2.2), either require or ask their members to attend regular group meetings. For example Asmitha Microfin Ltd. from India asks its members to attend weekly meetings in order to share and exchange their individual and group experiences with the other members of the bank. Through these activities, they are supposed to generate a better understanding and confidence about their options and achievements (Asmitha Microfin Limited, 2004). Other banks offer education through workshops or training on an individual basis. For example, Grameen Koota offers regularly workshops and training, which is very much community based and can be attended voluntarily (Grameen Koota, 2009).

The four MFIs, which were found to offer some form of Financial Education, are Banco Compartamos, S.A., Institución de Banca Múltiple from Mexico, Bangladesh Rural Advancement Committee (BRAC) from Bangladesh, Crédito con Educación Rural from Bolivia and Fundacion Para La Promocion y el Desarrollo from Nicaragua. It shall be highlighted, that three of them are based on the South American continent and that one is based in Asia.

On their website, the Mexican MFI Banco Compartamos, S.A., Institución de Banca Múltiple claims to develop close customer contact through personal meetings with their clients (see appendix 3). Furthermore, they state that Banco Compartamos supports its clients in the creation of microbusinesses along with teaching them about their opportunities in saving. Also, they describe to develop a "culture of savings" among their clients by stressing the importance of savings and developing individual strategies for paying back loans and saving money in individual meetings with their customers (Compartamos Banco, 2011).

Bangladesh Rural Advancement Committee (BRAC) from Bangladesh, on the other hand, offers an initiative called Social and Financial Empowerment of Adolescents (SOFEA) (see appendix 3). According to BRAC, this initiative aligns training components from different fields with each other and is solely focused at women. BRAC states that the aim of this program is to teach adolescent girls social awareness, business topics, such as how to create income-generating activities as well as a sense of respect and support from the community they live in. For BRAC, financial literacy training goes along with the education of the above-described topics and consists of business-related topics such as how to take a loan in order to create a business or how to save earnings. BRAC also describes that it offers "a secure place to socialize" (BRAC, 2011).

Crédito con Educación Rural (CRECER) from Bolivia offers a different perspective of Financial Education, which is solely aligned with Entrepreneurial Education (see appendix 3). Their clients can take advantage of 
Entrepreneurial Education programs in the form of group workshops, which help them to improve their business and cover topics such as budget planning, the direction of a business. Along with that, the MFI offers what they refer to as Financial Education, that is, education in budget planning and the use of banking services (CRECER, 2011).

The fourth MFI, which was found to offer some form of Financial Education, is Fundacion Para La Promocion y el Desarrollo from Nicaragua (see appendix 3). This MFI uses games, videos and other "entertainment-media" as mechanisms to educate its clients about the basic administration of money and topics such as how to spend money carefully, how to pay for one's debt and how to save money (ASOMIF, 2011).

\section{Findings}

The finding section is divided into two parts. The first part is the results obtained from the data collected from the websites of the MFIs in the sample while the second part results from the interviews carried especially to enable the author better interpret the web-based findings.

\section{1. Finding from web-based data}

With regard to RQ1a, the findings support the previous assumption that a GFE does not exist in any form. 8\% of the MFIs of the total sample or $22 \%$ of the MFIs, which do offer education for their clients, were found to offer some type of Financial Education. However, these types of Financial Education differ from GFE. In three of the four cases, the Financial Education, which was found to exist, consisted of an education focused on the proper use and functioning of basic Financial Products along with Entrepreneurial Education. In one case, Financial Education was mentioned to consist of increasing the awareness of the importance of savings.

Furthermore, with regard to RQ1b several types of education can be classified. Figure 5 summarizes and illustrates the findings of the previous research with regard to this second research question. Here the methods or education is differentiated, first, passive and active methods of education.

Second, direct and indirect modes of education are differentiated. Third, group and individual education is differentiated. Some MFIs offer education in the form of group workshops and activities whereas other MFIs offer education on an individual basis. Both forms have been recorded and both have been considered valid and beneficial methods. On the one hand, group meetings can build trust within a community and are likely to generate mutual support. Furthermore, as the group members all have different experiences, a great diversity of educational aspects can arise which can further enrich the intensity of the education. However, this is likely to lead to better results if there is high cohesion among the community and if the community is relatively small. In certain cases, individuals might also feel pressured or ashamed to share their experiences with their community. At this point as well as in more developed, bigger communities, an individual education is likely to be a more appropriate way to teach individuals.

Finally, the subject of the education is classified as well. As described previously, the outcome of this research supports the assumption that Entrepreneurial Education is the most prominent subject of education, which is being provided in the sector. $8 \%$ of the total sample or $22 \%$ of MFIs in the sample, which offer education provide on Entrepreneurial education.

Banco Compartamos S.A., for instance, offers an education, which is active, direct, and individual and covers the subjects of Financial and Entrepreneurial education. This bank also seems to operate in more developed areas and bigger communities which support the previous statement that individual education is likely to be more appropriate for bigger cities where no complete communities would become member of an MFI.

Bangladesh Rural Advancement Committee, Crédito con Educación Rural and Fundacion Para La Promocion y el Desarrollo all offer active, direct, and group education in the subject of Finance. Bangladesh Rural Advancement Committee offers additional Entrepreneurial and School education and Crédito con Educación Rural also offers Entrepreneurial, Social and Health education.

Therefore, according to the outcomes of the web-based research all Financial Education offered have their limitations as they only consist of selective methods, modes, forms and incorporate only selective financial topics bound to the respective MFI.

\subsection{Findings from the interviews}

We present the interview with Karl Strempel who has worked as a project manager for Muhammad Yunus provided valuable insights into financial education practices of MFIs. The Grameen lab also provided deep insights but there was nothing new that all the guys interviewed from Grameen lad added to what Karl Strempel gave especially as regards the topic of the study. This suggested a theoretical saturation especially upon talking to Karl who not only worked for Grammed but also worked for several MFIs in South America, those in top 50. He also consulted with the regulators in Bangladesh, India and South America so he had really in-depth insights into the topic of financial education, financial literacy and the connection with financial inclusion. I also had deep insights from Kiva Microfinance Kenya who co-opt other MFIs to carry out the financial education on their behalf across the globe. 
The findings were still very much similar to the experience of Karl and Grameen lab.

First, the outcomes of the interview support the assumption that GFE does not yet exist in practice. According to the interview findings, there is no formal program that directly and actively provides GFE for the poor. Having worked for Grameen, he said that they only provided weekly group meetings where customers had to pay back their rates as opposed to a formal education system. If somebody could not pay back their rate, the village community would discuss what could be done to address the issue (Strempel, 2019). Therefore, it can be concluded that this is an indirect and passive mechanism of group education, because the micro-clients only learn from actual case studies of their peers and are taught to behave in a certain way because of peer pressure that is to produce high repayment rate.

Furthermore, the interview found out that even though MFIs had a social aim they were still businesses as well, which needed to create certain revenue in order to be sustainable in the long term. Therefore, according to Strempel who has direct insights into the structure and actions of the Grameen bank, this institution would never give information or education to its customers that would enable them realize other appropriate product offerings from other MFIs (Strempel, 2019).

All in all, these statements strongly support the existence of SFE in the industry which is shaped by the selfinterest of the respective MFIs to gain and retain as much customers as possible in order to become a sustainable institution in the long term. The study also supports the existence of different methods, modes, forms and subjects of education provided by MFIs.

With these insights, it can be concluded that GFE is very much likely to lead to better results for the poor than SFE if practiced in a proper manner.

\section{Discussion}

This chapter has been dedicated to discuss the findings of the study. It has specifically focused on the implications of the findings for academia and practice. Finally limitations and implications and questions for future research have been elaborated before giving the conclusion for the study rather than the other way round due to the nature of the study.

\subsection{Theoretical Implications}

This study has led to some implications for researchers. It has provided a novel concept of GFE to scholars in the field of microfinance. The study has also distinguished Financial Literacy from Financial Education and illustrated the financial education may not necessarily lead to financial literacy particularly if SFE adopted at the expense of GFE.

In particular, the results of this study stress the urgency for an in-depth research into how financial education in microfinance can be improved. This is because it has been illustrated that the Microfinance industry has been flooded with commercial investors in recent years that focuses more on profit rather than the alleviation of poverty (Greeley, 2006). It is even worse now with the Emergence of Fintech which is worrying since both World bank and Microfinance Exchange, a renowned US based NGO are now giving less attention to MFIS but not providing data about micro-finance as they used to do but shift focus and attention to Fintech. In that regard, since the poor operate very closely at the margin, the need for a mechanism which allows them make informed financial decisions with regards to financial products and appropriate financial institutions is paramount and urgent.

Furthermore, this study has shed new light on the issue of Financial Education by elaborating the different types of education that are being provided in the industry. The results of the web-based research served as a basis to introduce a framework with which the different types of education can be classified according to method, mode, form and the subject of the respective education type. Also, advantages and disadvantages of each sub-type of financial education have been identified.

Basically, this study was only a first step that introduced Global Financial Education. The concept has been introduced and a typology of financial education has been identified. However, there is a lot of room and a great need for future research, which will further enrich the findings of this study.

\subsection{Managerial Implications}

The results of this study have some important implications for managers in the Microfinance sector as well as in other public and private sectors and NGOs that invest in microfinance. MFI managers who are involved in the Microfinance sector have to understand the urgent need for the provision of objective and sound financial education that enables micro-clients obtain optimum benefits from microfinance.

Since the Microfinance industry is evolving, there is a lot of movement in the sector as many MFIs enter or leave the market. This increasing commercialization in the sector is threatening the essential purpose of Microfinance. Thus, it is very important that, as the industry further grows, MFIs that are true to their essential role in society penetrate more the market, diminishing possibilities for MFIs that subverts the goal of microfinance. For this to take place, the study suggests, there is a need for GFE. This is because through GFE, the bargaining 
power of micro-clients will increase. Porter has described how this can work in his five forces model, bargaining power of informed customers. Through Global Financial Education micro-clients will be informed customers and therefore empowered to tell advantageous from disadvantageous MFIs. This process will increase the market share of advantageous MFIs and, on the other hand, pose a threat to disadvantageous MFIs. Eventually this process could force the disadvantageous MFIS out of the market. In that regard, institutions and /or organizations that fight towards poverty alleviation through microfinance ought to advocate for GFE.

Microfinance ideals is based on the idea that individuals have access to microfinance (micro-credit + microsavings + micro-literacy in order to become micro-entrepreneurs. However, MFIs tend to overlook the necessity of micro-literacy. In fact the term is almost non-existent. However, before becoming micro-entrepreneurs they need to become micro-literates in the first place. Moreover, the education they need has to exist in topics, which are relevant to their micro-communities. Figure 6 suggests topics, which could comprise micro-literacy. Thus microliterates should understand which micro-products exist for them and how they can select the right products. Also, among other topics they should be able to understand appropriate interest rates and payback schemes as well as how to select an advantageous MFI and how to quit from an existing relationship with an MFI, in other words, their entry as well as their exit strategy.

\subsection{Limitations and Future Research}

This study was only a first step in creating an understanding of the need for GFE and its possible outcomes. The study has some limitations that that can be refined with further studies.

First of all, the sample, which was used to conduct the research, was limited to 51 MFIs. Although it provided a good geographical distribution among the numerous continents and countries where MFIs exists, it only represents a very small fraction of about 3\% of the 1900 MFIs which are being listed by the Microfinance Information Exchange (Microfinance Information Exchange, 2010).

A further limitation of this study is that the investigation of RQ1 has mainly consisted of web-based research of whether and what form of education is currently being provided by the MFIs. The results and interpretations of this study therefore rely on the interpretations of the findings on the respective websites. Future research could conduct and investigate comprehensive interviews with the leaders of these MFIs in order to gain more in depth insight into their actions, their aim and their dedication in educating their clients. This could also create a better understanding of the MFI mangers themselves for the need for a Global Financial Education. Some of these managers are mislead by only focusing on the commercial gains of Microfinance. In depth interviews with MFI managers could also increase their consciousness of the social mission of Microfinance and support the essential developments of Microfinance.

Moreover, according to the circumstances only one of the two intended interviews with the purpose of enhancing the research through perspectives of experienced practitioners was evaluated. As this was only one person, the findings might be skewed towards the respondent's specific experiences. Future research could conduct a comprehensive set of interviews with industry leaders or specific leaders of MFIs to have a representative view. But since interview was done by an industry, the perspective was not that of only one microfinance but experience with several microfinance and regulator hence its validity.

Another limitation of the research is that no ranking according to social measures and the social benefits of MFIs exist. Therefore, the sample, which was used for this study, consisted of the most successful MFIs from a financial perspective. However, in the future, as the social benefits of MFIs are becoming increasingly important and present, a ranking which does include measures for the social benefits of an MFIs is more likely to lead to significant results.

Future Research needs to investigate the role of the proposed global financial education on the improvement of MFIs business models towards achievement of financial inclusion. It would also be important that future research investigates the impact of increased savings among MFI clients on their financial inclusion. An interesting avenue for future research could also be the creation of a more comprehensive and up-to-date ranking of the Top Microfinance Institutions in the market. This ranking could include financial as well as social measures and it could be sortable according to these different measures. Also, this database should include measures, which can be updated on a yearly basis in order to provide an updated list of the Top MFI institutions. Such a database could deeply enrich the present knowledge about the Microfinance industry and support individuals to better judge among the different MFIs. Furthermore, the more prominent it would become, this ranking could foster competition of all aspects in the industry. It is very much likely that as customers get informed about such a ranking, they would only want to become clients of those MFIs which provided the best service and programs for their customers.

Another important path for future research is to develop a conceptual framework GFE. This study has only served as an introduction to the completely novel concept. However, a more comprehensive research is needed which would allow academia to better understand the exact type of GFE, which shall be introduced. Such a conceptual framework should take into account the scope of the education, the form in which it will be provided 
and the possible outcomes and benefits for the customers which can take advantage of it.

\section{Conclusion}

This study sheds new light into the subject of education in Microfinance. It has introduced the novel concept of Global Financial Education to academia and it justified its relevance and the urgency for its introduction to microclients.

It has been shown that microfinance has the power to improve the life of the poor to a great extent. However, its power is being threatened by the commercialization of the sector. This recent trend has evolved into a danger for the poor now face many choices but lack the abilities to judge among them which will be beneficial and which will have negative results for them due to selective education by the MFIs and now Fintechs that are entering the MFIs space. Many micro-clients are already trapped in debt-cycles and depend on many loan sharks and MFIs. In Kenya, there is Fuliza product by Safaricom that is putting most of these micro-entrepreneurs in cycle of debt. In fact if you want to pay them with M-Pesa they refuse for fear that Safaricom will put that money into loan repayments directly. Global Financial Education is a mechanism to provide the poor with the relevant knowledge. By covering objective topics it gives them the knowledge to select among the various institutions and products only those, which are the most appropriate for them.

Nobel peace price laureates, such as Muhammad Yunus or Kofi Annan argue that access to finance is a human right and that they believe in the power and abilities of the poor. We need to become more aware of the negative developments in the sector. If the poor are given access to finance, they should also be given access to the opportunity to learn about what institutions and products are advantageous or disadvantageous for them. Introducing Global Financial Education to practice will be the just and fair step to do so.

\section{References}

AgroInvest. (2010, January 1). AgroInvest. Retrieved April 11, 2011 from AngroInvest Annual Report 2009: http://www.agroinvest.org/uploads/documents/AgroInvest Annual Report 2009.pdf

Al Amana Microfinance. (2010, Jauary 1). Al Amana Microfinance. Retrieved April 12, 2011 from Produits: http://www.alamana.org.ma/

Amhara Credit and Saving Institution (ACSI) . (2008, January 1). Amhara Credit and Saving Institution (ACSI) . Retrieved April 12, 2011 from Products and Services: http://www.acsi.org.et/Products\%20and\%20Services.htm

ASA. (2011, January 1). ASA. Retrieved April 12, 2011 from ASA at a Glance as of 2010: http://www.asa.org.bd/ataglance 2010.pdf

Asli Demirguc-Kunt, L. K. \& D. S. (2017). What do we know about the link between financial inclusion and inclusive growth? New York. Retrieved from https://blogs.worldbank.org/allaboutfinance/what-do-weknow-about-link-between-financial-inclusion-and-inclusive-growth

Asmitha Microfin Limited. (2004, January 1). Asmitha Microfin Limited. Retrieved April 12, 2011 from Products and Services: http://www.asmithamicrofin.com/inside/product/product.html

ASOMIF. (2011, January 1). ASOMIF. Retrieved April 16, 2011 from Educacion Financiera: http://www.asomif.org/index.php?option=com_content\&view=article\&id=59\&Itemid=30

Bank, T. W. (2018). UFA2020 Overview: Universal Financial Access by 2020. New York.

ürger Verband für Zukunftssicherung e.V. (2010, January 1). Mikrofinanz. Retrieved February 3, 2011 from Bürger Verband für Zukunftssicherung e.V.: http://www.bvfz.de/index.php?id=70

Buro Bangladesh. (2007, January 1). Buro Bangladesh. Retrieved April 13, 2011 from About Buro: http://www.burobd.org/about.php

Badhan. (2011, January 1). Badhan. Retrieved April 13, 2011 from Products and Services: http://www.bandhanmf.com/faq.aspx\#

Banco do Nordeste. (2011, January 1). Banco do Nordeste. Retrieved April 12, 2011 from Crediamigo Produtos: http://www.bnb.gov.br/content/aplicacao/Produtos e Servicos/Crediamigo/gerados/produtos.asp

Bateman, M., \& Chang, H.-J. (2009). The Microfinance Illusion. Cambridge: University of Cambridge.

Bernau, P. (2011, January 30). Kleine Kredite, goße Summen. Frankfurter Allgemeine Sonntagszeitung (4), p. 45.

Bernau, P., \& Hein, C. (2011, January 30). Arme Bauern in der Schuldenfalle. Frankfurter Allgemeine Sonntagszeitung, p. 45.

Brau, J. C., \& Woller, G. M. (2004). Microfinance: A Comprehensive Review of the Existing Literature. Journal of Entrepreneurial Finance and Business Ventures , 9 (1), 1-26.

BRAC. (2011, January 1). BRAC. Retrieved April 13, 2011 from Microfinance: http://www.brac.net/content/microfinance

Caja Municipal Cusco. (2011, January 1). Caja Municipal Cusco. Retrieved April 13, 2011 from Productos: http://www.cmac-cusco.com.pe/

Caja Trujillo. (2011, January 1). Caja Trujillo. Retrieved April 13, 2011 from Productos: 
http://www.cajatrujillo.com.pe/portalnew/productos_parati_paratunegocio.html

Cohen, M., Stack, K., \& McGuiness, E. (2004, July 31). Financial Education: A Win-Win for Clients and MFIs. Retrieved February 8, 2011 from Microfinancegateway: http://www.microfinancegateway.org/p/site/m/template.rc/1.26.9044/

Compartamos Banco. (2011, January 1). Compartamos Banco. Retrieved April 12, 2011 from Financial Education: http://www.compartamos.com/wps/portal/!ut/p/c1/fY5BDoIwEEXPwglm0kqLyzY2bSEp1khENqQLY2oE XBjPL8aVRPpn-fLmfhgvjG84jU84zSGO7TQsX5vcMuNJlg3eoeECnkgZU4rhzM_r_MSU7YkC1tLr9AWiuaCVcgk_7G1Pwq0t TPC04IYlcPpszbdnuKUfTmuRCz9P tS zkFZ6bhAohaTHa20Zk2Ru0Oi1w/dl2/d1/L2dJQSEvUUt3QS9ZQnB3LzZfUEgwOTdIRzIwR0JRRTBJOEUzNUE2Sz A2UjQ!/?mosHist=1

CRECER. (2011, January 1). CRECER Institución Financiera de Desarrollo. Retrieved April 13, 2011 from Nuestros Servicios: http://www.crecer.org.bo/index.php?mc=59

CREDIFE. (2011, January 1). CREDIFE Desarrollo Microempresarial. Retrieved April 13, 2011 from Nuestra Empresa: http://www.credife.com/

EKI. (2011, January 1). EKI. Retrieved April 13, 2011 from Mission and Vision: http://www.eki.ba/en/index.php?option=com_content\&view=article\&id=22\&Itemid $=44$

Enda Inter-Arabe. (2011, January 1). Enda Inter-Arabe. Retrieved April 13, 2011 from About Enda: http://www.endarabe.org.tn/index.php?option=com_content\&view=article\&id=48\&Itemid=113\&lang=en.

Dunford, C. (2002). Building Better Lives: Sustainable Integration of Microfinance with Education in Child Survival, Reproductive Health, and HIV/AIDS Prevention for the Poorest Entrepreneurs. Pathways Out of Poverty: Innovations in Microfinance for the Poorest Families. Fairfield, CT, Kumarian Press.

Dunsch, J. (2011, January 27). Weltwirtschaftsforum: Davos ohne Yunus. Frankfurter Allgemeine Zeitung .

DBACD. (2011, January 1). Dakahlya Businessmen's Association for Community Development. Retrieved April 13, 2011 from DBACD's Range of Products: http://www.dbacd-eg.org/MFI/Products/Products.html

Dedebit Microfinance. (2011, April 13). Dedebit Microfinance. Retrieved April 13, 2011 from Operations: http://www.decsi.com.et/operations.html

Frisancho, V., Karlan. D., \& Valdivia, M. (2008). Business Training for Microfinance Clients: How it Matters and for Whom? Power and Economic Policy Research Network.

Funación Mundo Mujer. (2011, January 1). Funación Mundo Mujer. Retrieved April 14, 2011 from Nuestros Servicios: http://www.fmm.org.co/index.php?section=25

Fundación Mundial de la Mujer . (2011, January 1). Fundación Mundial de la Mujer . Retrieved April 13, 2011 from Productos

$\mathrm{y}$ http://www.fundaciondelamujer.com/productos_servicios/productos_servicios.aspx

FINCA. (2007, January 1). FINCA. Retrieved April 13, 2011 from Nuestros Productos: http://www.bancofinca.com/FINCA/nuestrosProgramas.aspx

Fondation Micro-Credit. (2009, January 1). Fondation Micro-Credit. Retrieved April 14, 2011 from Nos Produits: http://www.fbpmc.ma/\#fr_mc-profesionel

Fondep. (2011, March 9). Fondep. Retrieved April 14, 2011 from Home: http://www.fondep.com/ang/default.htm

Fondi Besa. (2008, January 1). Fundi Besa. Retrieved April 13, 2011 from Mission: http://www.fondibesa.com/en/index.html

Grameen Bank. (2011, January 11). Grameen Bank. Retrieved April 14, 2011 from About Us: http://www.grameeninfo.org/index.php?option=com_content\&task=view\&id=792\&Itemid=759

Grameen Koota. (2009, January 1). Grameen Koota. Retrieved April 14, 2011 from New Initiatives: http://www.gfspl.in/Beyond Credit.html

Greeley, M. (2006). IDS Working Paper 255 Microfinance Impact and The MDGs: The Challange of Scaling-up. University of Sussex . Brighton: Institute of Development Studies .

Griffith-Jones, S., \& Ocampo, J. A. (2009, April 1). The Financial Crisis and its Impact on Developing Countries. Working Paper (53), pp. 1-17.

Helms, B., Littlefield, E., \& Porteous, D. (2015). FINANCIAL INCLUSION 2015 :, (39).

INECOBANK. (2011, February 18). INECOBANK. Retrieved April 14, 2011 from About Us: http://www.inecobank.am/index.php?page=about

Integrated Development Foundation. (2011, January 1). Integrated Development Foundation. Retrieved April 14, 2011 from Programs: http://www.idfbd.org/program_products.htm

Jappelli, T. (2009). Financial Literacy: An International Comparison. Naples: University of Naples Federico II.

Kazakhstan Loan Fund. (2006, Jaunary 1). Kazakhstan Loan Fund. Retrieved April 14, 2011 from Produkt: http://www.kclf.kz/eng/viewpage.php?page_id=21

Kazmin, A. (2010). Small Loan, Big Snag. Financial Times, Thursday December 2, 2010.

Kashf Foundation. (2007, January 1). Kahsf Foundation. Retrieved April 14, 2011 from Products and Services: 
http://www.kashf.org/site_files/products.asp

Khan Bank. (2010, January 1). Khan Bank. Retrieved April 13, 2011 from Abou Us: http://www.khanbank.com/en/35/About-Us.html

Khandker, S. R. (2005). Mircofinance and Poverty: Evidence using Panel Data from Bangladesh. The World Bank Economic Review , 19 (2), 263-286.

Khumawala, S. B. (2009). A Model for Microfinance-Supported Education Programs; The Deans Perspective, Decision Line.

Littlefield, E., Murduch, J., \& Hashemi, S. (2003). Is Microfinance an Effective Strategy to Reach the Millennium Development Goals? Focus Note , 4, 1-19.

Nair, T. S. (2010). Commercial Microfinance and Social Responsibility: A Critique. Economic and Political Weekly, 45 (31), 32-37.

Narayan, D., Chambers, R., Shah, M. K., \& Petesch, P. (2000). Voice of the poor: Crying out for change. New York: Oxford University Press.

Madura Microfinance Ltd. (2011, January 1). Madura Microfinance Ltd. Retrieved April 16, 2011 from Microeducation: http://www.maduramicrofinance.com/app_microeducation.html

Mair, J., \& Marti, I. (2009). Entrepreneurship in and around institutional voids: A case study from Bangladesh. Journal of Business Venturing , 24, 419-435.

Microcredit Organization Sunrise. (2005, January 1). Microcredit Organization Sunrise. Retrieved April 14, 2011 from Credit Products: Microcredit Organization Sunrise

Microfinance Information Exchange. (2010). Annual Report 2010. Washington D.C.: Microfinance Information Exchange, Inc.

Microfinance Information Exchange. (2010, January 1). Microfinance at a Glance. Retrieved April 6, 2011 from Microfinance Information Exchange: http://www.mixmarket.org/

Microfinance Information Exchange. (2010, January 1). Microfinance Information Exchange. Retrieved April 6, 2011 from Microfinance Institutions: http://www.mixmarket.org/mfi

MIKROFIN Banja Luka. (2009, January 1). MIKROFIN Banja Luka. Retrieved April 14, 2011 from Proizvodi i usluge: http://www.mikrofin.com/index.aspx

Miller, M., Godfrey, N., Levesque, B., \& Stark, E. (2009). The Case for Financial Literacy in Developing Countries. Washington: The International Bank for Reconstruction and Development/The World Bank.

MkNelly, B., C. Watetip, C. A. Lassen and C. Dunford (1996). "Preliminary Evidence that Integrated Financial and Educational Services can be Effective against Hunger and Malnutrition." Freedom from Hunger Research Paper Series 2.

Montgomery, H., \& Weiss, J. (2004). Great Expectations: Microfinance and Poverty Reduction in Asia and Latin America. Tokyo: ADB Institute Discussion Paper.

Morduch, Jonathan (1999). "The Microfinance Promise." In Journal of Economic Literature 37 (4): 1569-1614, December

(1998). "Does Microfinance Really Help the Poor? New Evidence of Flagship Programs in Bangladesh". manuscript, June. Available at: http://www.wws.princeton.edu/ rpds/macarthur/downloads/avgmp\%7E6.pdf

Otero, M. (1999). Bringing Development Back Into Microfinance. Frankfurt: ACCION International.

Partner. (2011, January 1). Partner. Retrieved April 14, 2011 from Home: http://www.partner.ba/index.php/en/home.html

Pitt, M. M., \& Khandker, S. R. (1998). The Impact on Group-Based Credit Programs on Poor Households in Bangladesh: Does the Gender of Participants Matter?Gender. Journal of Political Economy , 106 (5), 958996.

Porter, M. E. (1979, March 3). The Five Competitive Forces That Shape Strategy. Harvard Business Review , pp. 23-41.

Prahaland, C. (2009). The Fortune At The Bottom Of The Pyramid: Eradicating Poverty Through Profits. Pennsylvania: Pearson Education.

Programas para la Mujer . (2007, January 1). Programas para la Mujer - Peru. Retrieved April 14, 2011 from Integrated Services: https://promujer.org/index.tpl?\&ng_view=33

Swibel, M. (2007, December 20). The World's Top 50 Microfinance Institutions. Retrieved March 29, 2011 from Forbes: http://www.forbes.com/2007/12/20/top-microfinance-philanthropy-biz-cz ms 1220intro.html

Swibel, M. (2007, December 20). The Top 50 Microfinance Institutions. Retrieved March 31, 2011 from Forbes: http://www.forbes.com/2007/12/20/microfinance-philanthropy-credit-bizcz ms 1220microfinance table.html

Saadhana Microfin Society. (2005, January 1). Saadhana Microfin Society. Retrieved April 14, 2011 from Methodology: http://www.saadhana.org/Identification\%20Of\%20Potential\%20Area.html\#IGO

Sanasa Development Bank. (2011, January 1). Sanasa Development Bank. Retrieved Janaury 1, 2011 from 
Community: http://www.sdb.lk/com_c.asp

Sebstad, J., \& Cohen, M. (2003). Financial Education for the Poor. Washigton: Microfinance Opportunities.

Shah, A. (2010, September 20). Poverty Facts and Stats. Retrieved February 3, 2011 from Global Issues: www.globalissues.org/article/26/poverty-facts-and-stats

Shakti Foundation for Disadvantaged Women. (2011, January 1). Shakti Foundation for Disadvantaged Women. Retrieved April 15, 2011 from Programs: http://www.sfdw.org/index.php?option=com_content\&view=category\&layout=blog\&id=42\&Itemid=2

Sharada's Women's Association for Weaker Section. (2008, January 1). Sharada's Women's Association for Weaker Section. Retrieved April 15, 2011 from Methodology: http://www.sccimicrofinance.com/methodology2.php

SKS Microfinance Private Limited. (2009, January 1). SKS Microfinance Private Limited. Retrieved April 15, 2011 from Ultra Poor Programme: http://www.sksindia.com/ultrapoor_programme.php

Strempel, K. (2011, May 9). RQ1 and RQ2 - Insights from Grameen and a consultant point of view. (A. Wurczinger, Interviewer)

Reyada Development and Employment Fund. (2010, January 1). Reyada Development and Employment Fund. Retrieved April 13, 2011 from Administration Development and Training: http://www.defjo.com/site/en/2010-09-01-11-58-46/2010-09-01-12-00-03/2010-09-01-12-25-44

UNESCO Education Sector. (2004). The Plurality of literacy and its Implications for Policies and Programmes. Paris: United Nations Educational, Scientific and Cultural Organization.

Zakoura Micro-Credit. (2005, January 1). Zakoura Micro-Credit. Retrieved April 14, 2011 from Produits: http://www.zakourafondation.org/rubrique.php3?id rubrique=2\&id parent=2\&ordre menu=1

WWB. (2011, January 1). WWB. Retrieved April 14, 2011 from Productos y Servicios: http://www.fwwbcol.org/index.php?option=com_content\&view=article\&id=112\&Itemid=22

Woller, G., \& Parsons, R. (2002). Assessing the Community Economic Impact of Microfinance Institutions. Journal of Developmental Entrepreneurship , 8 (2), 278-1770.

Yunus, M. (2010). Building Social Business. New York: Public Affairs.

Yunus, M. (1997). Banker to the Poor. New York: Public Affairs.

Yunus, M. (2010, October 1). Grameen Bank at a Glance. Retrieved January 31, 2011 from Grameen Bank: www.grameen.com

Yunus, M. (2010, October 1). Is Grameen Bank different? Retrieved January 30, 2011 from Grameen Bank: www.grameen.com

Yunus, M. (2011, January 14). Sacrificing Microcredits for Megaprofits. The New York Times .

\section{Notes}

End Notes:

Purpose: The study's aim is threefold. First, the study aims to justify that one of the reasons why Microfinance Institutions, throughout the globe, have not achieved its intended purpose, that is, help transition the poor and the low income earners into financial inclusion is their failure to offer the right financial education that provides financial literacy. Second the Study aimed at analysing the method, the mode, form and subject of financial education currently carried out by the Microfinance Institutions globally to determine if the kind of financial education they offer can lead to financial literacy that is equivalent to what the study term as Global Financial Education instead of Selective financial education. Selective financial education does not provide their clients with the knowledge that would empower them amid the opportunities they have with the capital they access through micro-credit. Finally aims to develop a practical way in which Global financial education can be achieved.

Methodology: The study first reviewed the literature on impact studies to find out whether MFIs have achieved their intended purpose. The study then established the explanation from the literature with the hypothesis that it poor financial education that does not lead to financial literacy. The study then carried out a content analysis of the top 50 MFIs from 2,000 MFis ranked by Microfinance Exchange to determine the method, mode, form and subject of their financial education with the need to determine whether the financial education they offer can lead to financial literacy. The study also carried out interview with some of the key persons who have worked with several leading microfinance institutions and also worked at some of the regulatory bodies to interpret the results of content analysis.

Findings: First, from the review of the MFI body of knowledge, scholars generally agree that Micro-finance has not delivered its promise, at least in its current form hence needs for innovating its operations. In that regard, our proposition to change its mode of financial education is likely to add value to the impact of MFIs. Second, all the top 50 MFIs ranked by Microfinance Exchange offer Selective financial education that does not lead to financial literacy which is one of the reasons why MFIs as currently constituted may not realize its intended purpose. Third, $8 \%$ of the MFIs of the total sample or $22 \%$ of the MFIs, which do offer education for their clients do only focus on education for their clients in away that enhance their loyalty, not necessarily with the perspective of 
transforming from poor and low income into financial inclusion. The method, mode, form and subject of financial education offered by MFIs are insufficient as they are offered from the perspective of the MFI in question to its clients that cannot realize financial literacy hence a need to have a third party offer financial education to produce financially literate MFI clients who are able to reach the goal of financial inclusion.

Unique contribution to theory, practice and policy: The study contributes to the body of knowledge of microfinance by suggesting a new concept termed as Global Financial education as unbiased, unselective financial education that is capable of producing financial literacy. In practice the study distinguishes financial education (input) from financial literacy (output, outcome) and suggest a practical means to which MFIs can achieve financial literacy through Global financial education to their clients and intended clients rather than just delivering financial education that leaves its clients only knowledgeable about products and services of one MFI or some products and services of a particular MFI. This is because there is evidence to suggest that some of the MFI clients haven't achieved financial inclusion because they consume inappropriate financial product from inappropriate MFI, a challenge that can be addressed through Global Financial Education. The study recommends a more regulation for MFIs and the Fintech that have entered the MFIs space that keep the MFI clients in a vicious cycle of poverty due to the biased, selective financial education. The solution being setting up a school of Microfinance that anyone who needs to join any MFI needs to go in order to get generic financial literacy before being educated by the MFI in question. MFI colleges or education centres needs to be financed by key stakeholders in a partnership.

\section{List of tables}

Table 1. The capitals, assets and revenue in listed banks

TABLE 5: THE TOP 50 MICROFINANCE INSTITUTIONS IN ALPHABETICAL ORDER

\begin{tabular}{|c|c|c|c|c|c|c|c|}
\hline Rank & Name & Country & Continent & Scale & Efficiency & Risk & Returns \\
\hline 22 & Agrolnvest & Serbia & Europe & 84 & 195 & 222 & $\overline{11}$ \\
\hline 6 & Amhara Credit and Savings Institution & Ethiopia & Africa & 56 & 126 & 118 & 42 \\
\hline 1 & ASA & Bangladesh & Asia & 14 & 83 & 56 & 40 \\
\hline 29 & Asmitha Microfin Ltd. & India & Asia & 80 & 254 & 73 & 111 \\
\hline 8 & Association Al Amana for the Promotion of Micro-Enterprises Morocco & Morocco & Africa & 17 & 212 & 133 & 1 \\
\hline 7 & Banco Compartamos, S.A., Institución de Banca Múltiple & Mexico & South America & 15 & 24 & 295 & 11 \\
\hline 3 & Banco do Nordeste & Brazil & South America & 46 & 27 & 213 & 25 \\
\hline 2 & Bandhan (Society and NBFC) & India & Asia & 108 & 49 & 42 & 1 \\
\hline 21 & Bangladesh Rural Advancement Committee & Bangladesh & Asia & 10 & 159 & 126 & 205 \\
\hline 43 & BESA Fund & Albania & Europe & 109 & 135 & 345 & 1 \\
\hline 48 & BURO, formerly BURO Tangail & Bangladesh & Asia & 137 & 207 & 186 & 91 \\
\hline 41 & Caja Municipal de Ahorro y Crédito de Arequipa & Peru & South America & 23 & 126 & 220 & 215 \\
\hline 20 & Caja Municipal de Ahorro y Crédito de Cusco & Peru & South America & 48 & 99 & 222 & 119 \\
\hline 23 & Caja Municipal de Ahorro y Crédito de Trujillo & Peru & South America & 20 & 163 & 220 & 101 \\
\hline 11 & Consumer Credit Union 'Economic Partnership' & Russia & Europe & 82 & 300 & 19 & I \\
\hline 30 & Credi Fe Desarrollo Microempresarial S.A. & Ecuador & South America & 28 & 252 & 206 & 34 \\
\hline 42 & Crédito con Educación Rural & Bolivia & South America & 135 & 152 & 298 & 1 \\
\hline 28 & Dakahlya Businessmen's Association for Community Development & Egypt & Africa & 200 & 215 & 102 & 1 \\
\hline 31 & Dedebit Credit and Savings Institution & Ethiopia & Africa & 50 & 246 & 80 & 154 \\
\hline 45 & Development and Employment Fund & Jordan & Africa & 83 & 388 & 135 & 1 \\
\hline 14 & EKI & Bosnia \& Herzegovina & Europe & 66 & 102 & 242 & 1 \\
\hline 36 & enda inter-arabe & Tunisia & Africa & 198 & 90 & 257 & 1 \\
\hline 49 & Erste Bank (formerly: Opportunity Bank A.D. Podgorica) & Serbia & Europe & 49 & 234 & 319 & 23 \\
\hline 40 & FINCA - ECU & Ecuador & South America & 125 & 138 & 264 & 54 \\
\hline 12 & Fondation Banque Populaire pour le Micro-Credit & Morocco & Africa & 59 & 126 & 219 & 1 \\
\hline 27 & Fondation Zakoura & Morocco & Africa & 51 & 268 & 194 & 1 \\
\hline 5 & FONDEP Micro-Crédit & Morocco & Africa & 119 & 26 & 196 & \\
\hline 4 & Fundación Mundial de la Mujer Bucaramanga & Colombia & South America & 58 & 72 & 193 & \\
\hline 9 & Fundación Mundo Mujer Popayán & Colc & South America & 53 & 181 & 141 & 1 \\
\hline 33 & Fundacion Para La Promocion y el Desarrollo (ASOMIF) & Nice & South America & 173 & 89 & 171 & 100 \\
\hline 10 & Fundación WWB Colombia - Cali & Colc & South America & 27 & 206 & 155 & 4 \\
\hline 17 & Grameen Bank & Bangladesh & Asia & 8 & 280 & 100 & 62 \\
\hline 19 & Grameen Koota & India & Asia & 209 & 106 & 156 & 1 \\
\hline 26 & INECO Bank & Armenia & Europe & 96 & 173 & 202 & 39 \\
\hline 38 & Integrated Development Foundation & Bangladesh & Asia & 300 & 134 & 140 & 1 \\
\hline 16 & Jagorani Chakra Foundation & Bangladesh & Asia & 136 & 176 & 128 & 1 \\
\hline 34 & Kashf Foundation & Pakistan & Africa & 123 & 194 & 219 & 1 \\
\hline 37 & Kazakhstan Loan Fund & Kazakhstan & Europe & 120 & 118 & 320 & 1 \\
\hline 25 & Khan Bank (Agricultural Bank of Mongolia LLP) & Mongolia & Asia & 19 & 149 & 280 & 59 \\
\hline 47 & Kreditimi Rural i Kosoves LLC (formerly Rural Finance Project of Kosovo) & Kosovo & Europe & 213 & 158 & 247 & 1 \\
\hline 13 & Madura Microfinance Ltd. (formerly: Microcredit Foundation of India) & India & Asia & 75 & 142 & 7 & 185 \\
\hline 32 & MI-BOSPO Tuzla & Bosnia \& Herzegovina & Europe & 128 & 120 & 283 & 1 \\
\hline 39 & Microcredit Organization & Bosnia \& Herzegovina & Europe & 114 & 103 & 341 & 17 \\
\hline 24 & MIKROFIN Banja Luka & Bosnia \& Herzegovina & Europe & 60 & 240 & 205 & \\
\hline 18 & Partner & Bosnia \& Herzegovina & Europe & 64 & 169 & 230 & \\
\hline 46 & Programas para la Mujer - Peru & Peru & South America & 292 & 82 & 242 & \\
\hline 15 & Saadhana Microfin Society & India & Asia & 263 & 79 & 73 & 1 \\
\hline 50 & Sanasa Development Bank & Sri Lar & Asia & 86 & 206 & 93 & 241 \\
\hline 35 & Shakti Foundation for Disadv & Bangladesh & Asia & 170 & 221 & 151 & 1 \\
\hline 23 & Sharada's Women's Association for Weaker Section & India & Asia & 229 & 207 & 55 & 13 \\
\hline 44 & SKS Microfinance Private Limited & India & Asia & 61 & 395 & 141 & \\
\hline
\end{tabular}

Source: (Swibel, The World's Top 50 Microfinance Institutions, 2007) 


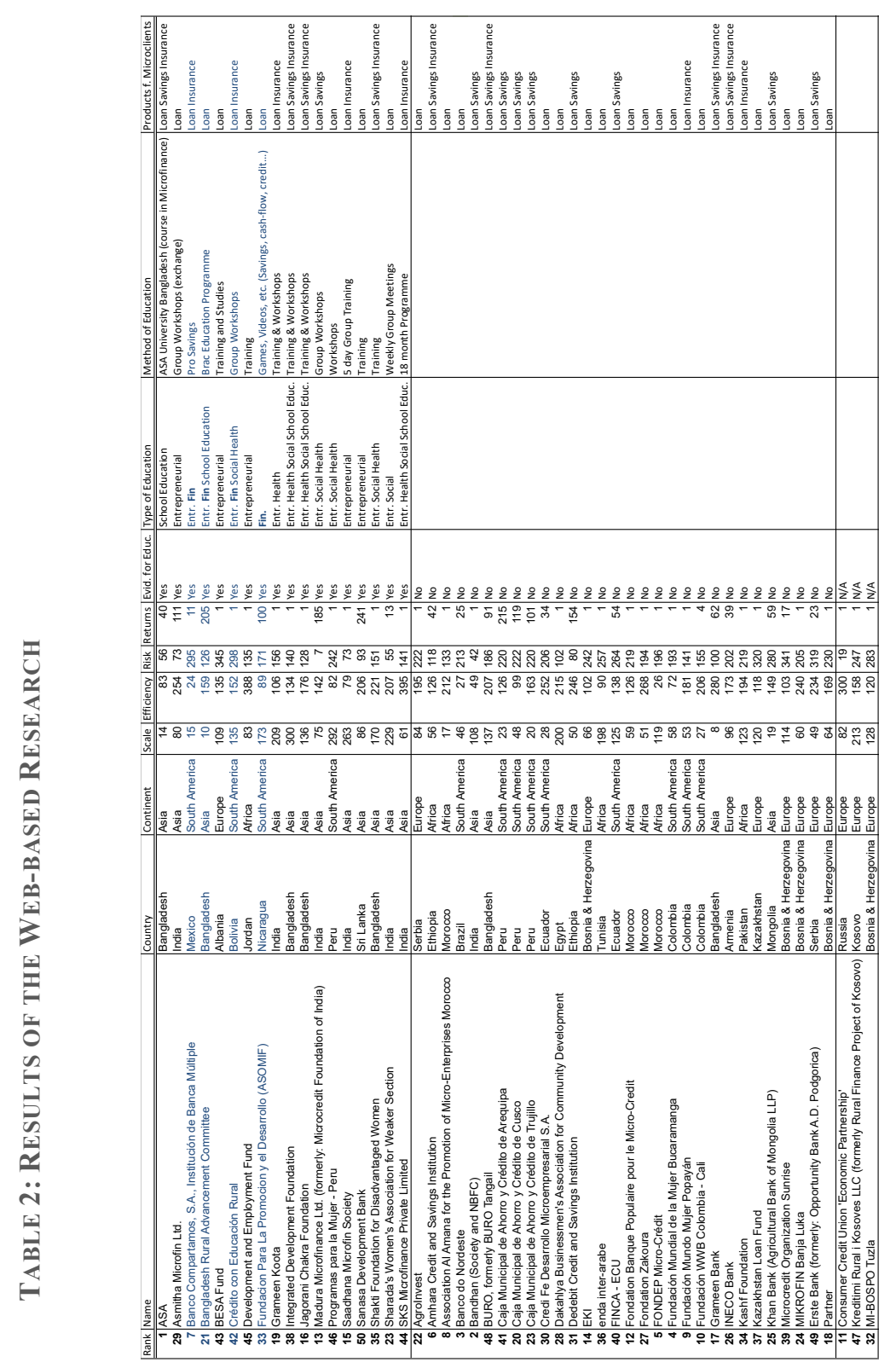




\section{List of Figures}

Figure 1: THE IMPACT OF GLOBAL FINANCIAL EdUCATION

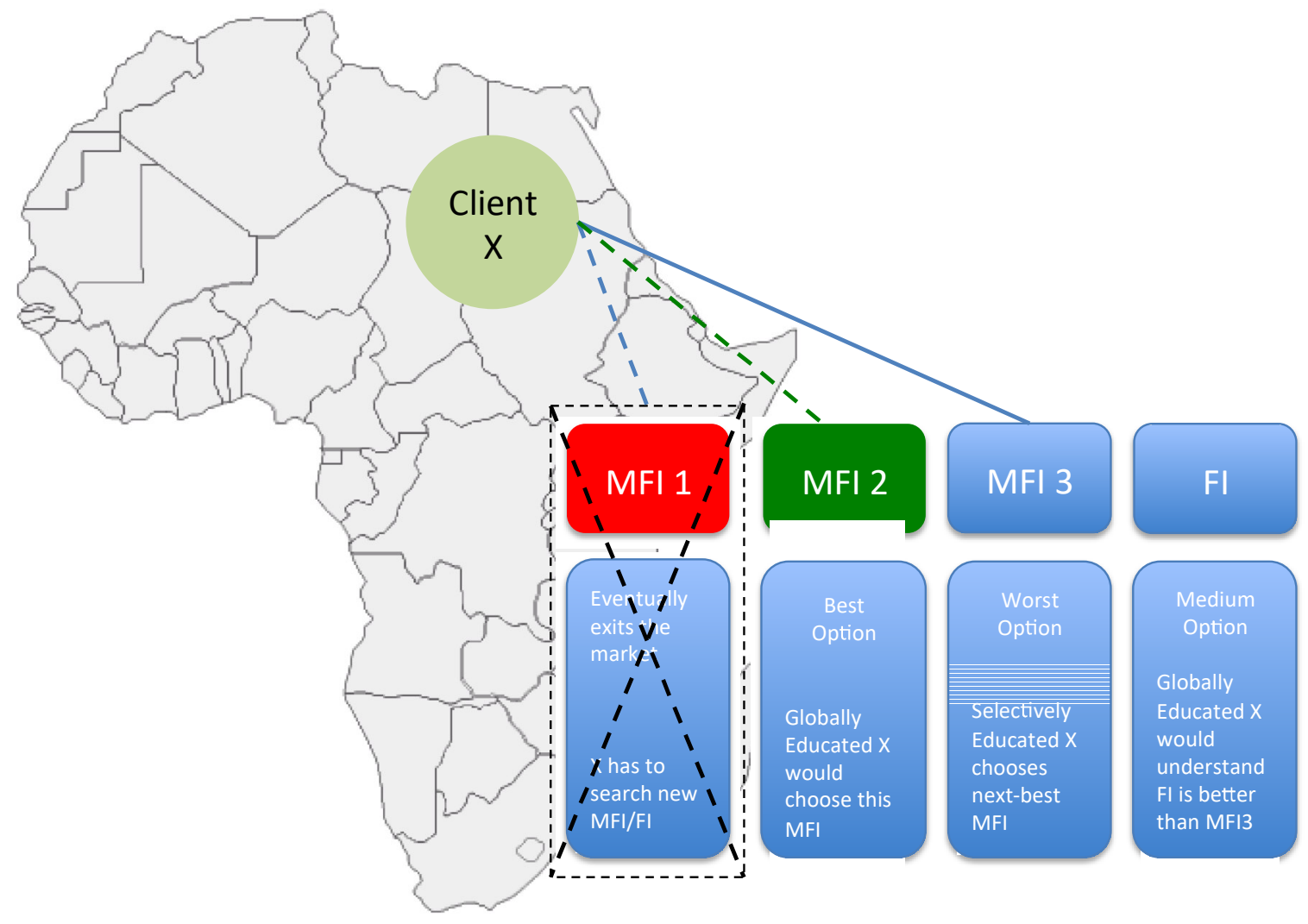

Source: Own

Figure 2: THE WIDER IMPACT OF MicrofinANCE

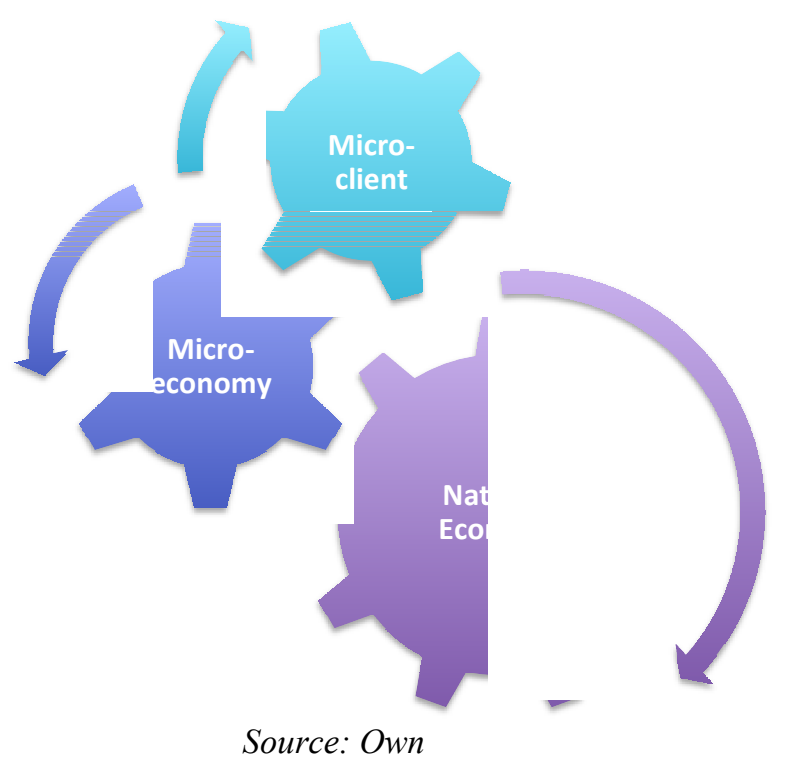

Figure 3A : OVERALl SAMPle by Region 


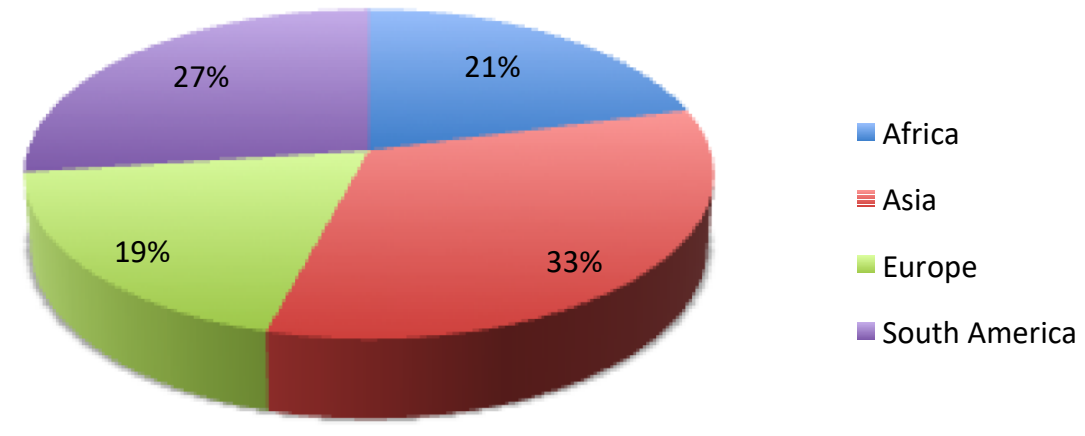

Source: Table 2

Figure 3B: EdUCATION OFFERED BY REGION

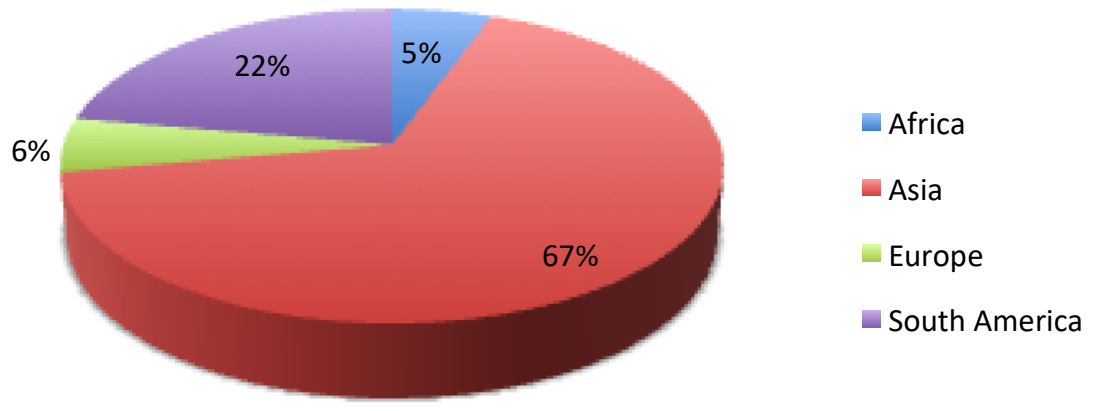

Source: Table 2

FIGURE 4: DISTRIBUTION OF THE DIFFERENT TYPES OF EDUCATION OFFERED 


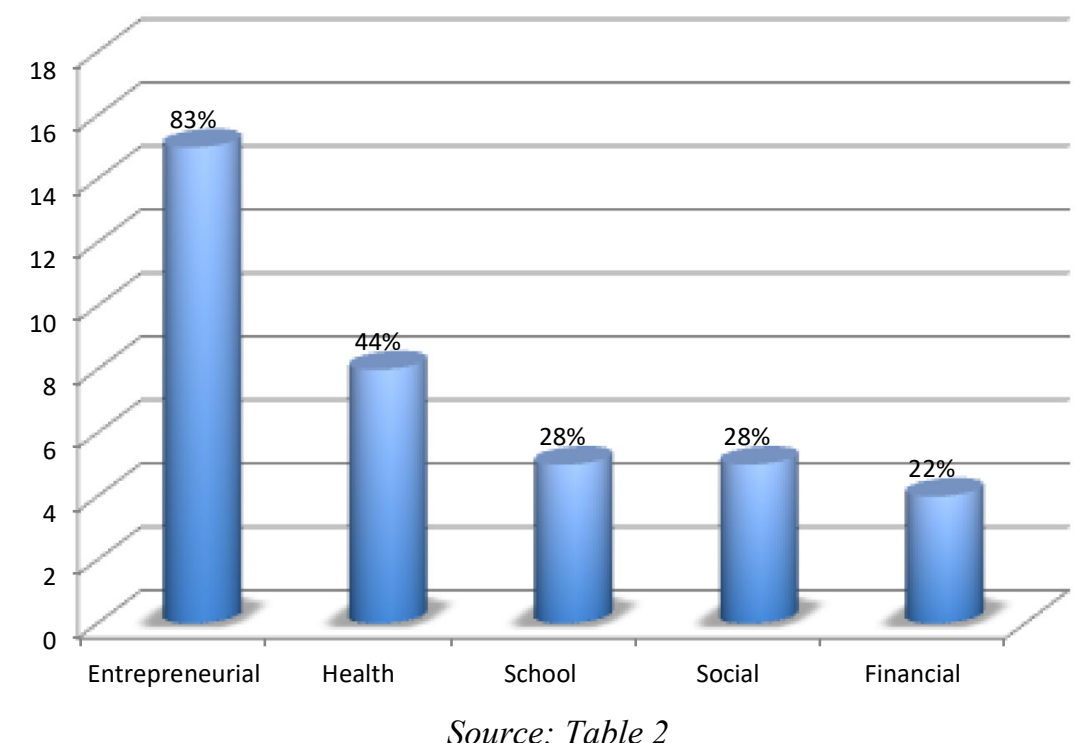

FIGURE 5: TYPOLOGIES OF EDUCATION OFFERED BY MFIS
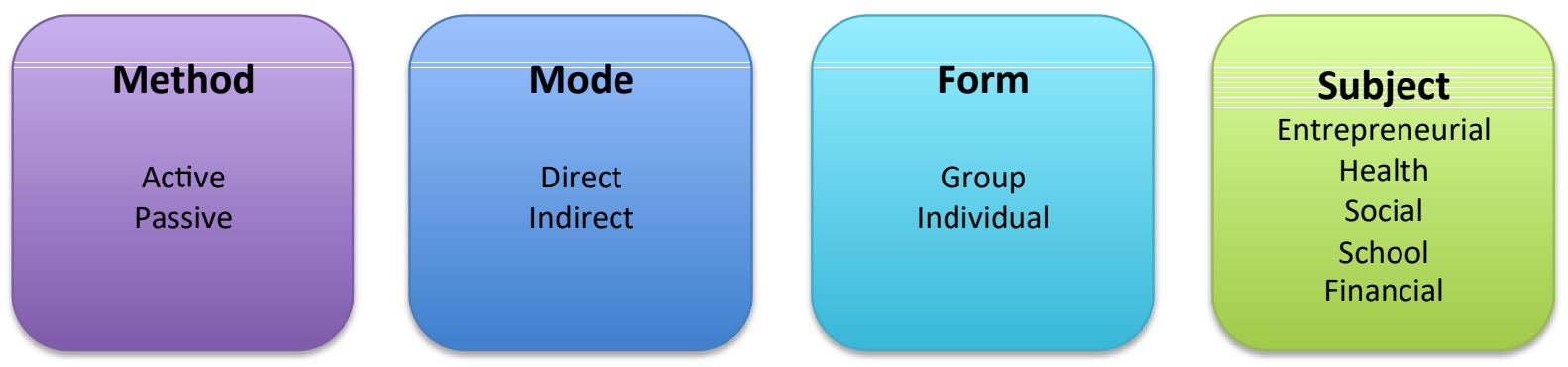

Source: Own

Figure 6: MiCRO LITERACY IN PRACTICE

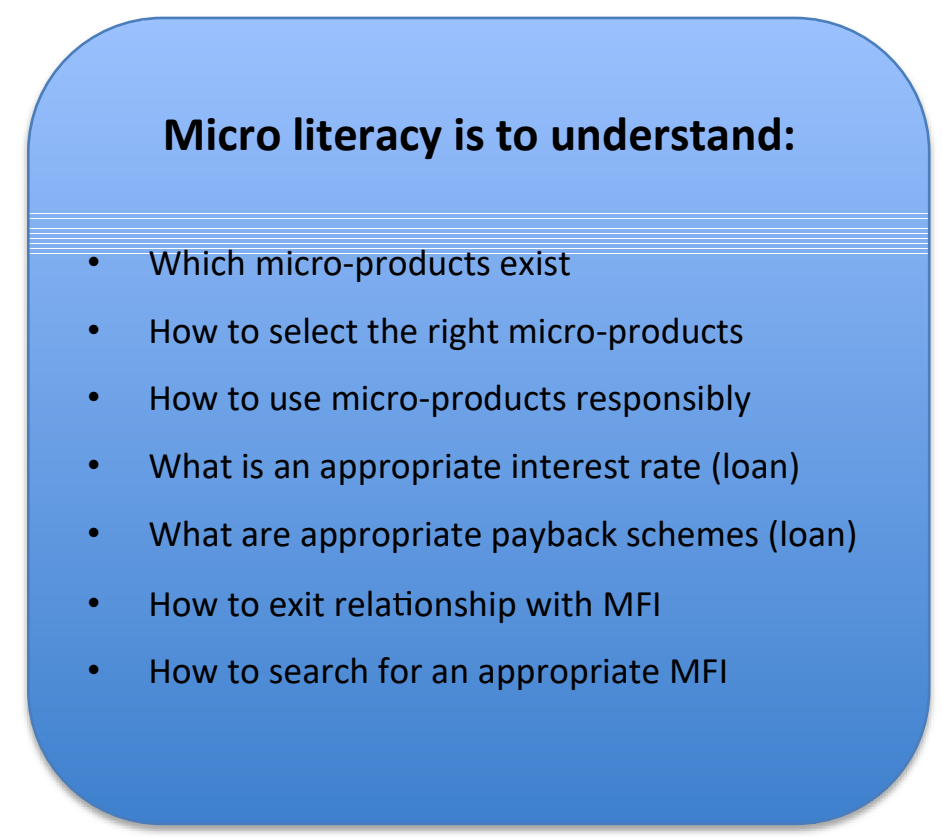

Source: Own

\section{Appendix 1: The 16 Decisions oft he Grameen Bank}

1. We shall follow and advance the four principles of Grameen Bank --- Discipline, Unity, Courage and 
Hard work - in all walks of our lives.

2. Prosperity we shall bring to our families.

3. We shall not live in dilapidated houses. We shall repair our houses and work towards constructing new houses at the earliest.

4. We shall grow vegetables all the year round. We shall eat plenty of them and sell the surplus.

5. During the plantation seasons, we shall plant as many seedlings as possible.

6. We shall plan to keep our families small. We shall minimize our expenditures. We shall look after our health.

7. We shall educate our children and ensure that they can earn to pay for their education.

8. We shall always keep our children and the environment clean.

9. We shall build and use pit-latrines.

10. We shall drink water from tube wells. If it is not available, we shall boil water or use alum.

11. We shall not take any dowry at our sons' weddings; neither shall we give any dowry at our daughters wedding. We shall keep our center free from the curse of dowry. We shall not practice child marriage.

12. We shall not inflict any injustice on anyone; neither shall we allow anyone to do so.

13. We shall collectively undertake bigger investments for higher incomes.

14. We shall always be ready to help each other. If anyone is in difficulty, we shall all help him or her.

15. If we come to know of any breach of discipline in any center, we shall all go there and help restore discipline.

16. We shall take part in all social activities collectively.

Source: http://www.grameen-info.org/index.php?option=com_content\&task=view\&id=22\&Itemid=109

\section{Appendix 2: Bibliography of the web-based research}

AgroInvest. (2010, January 1). AgroInvest. Retrieved April 11, 2011, from AngroInvest Annual Report 2009: http://www.agroinvest.org/uploads/documents/AgroInvest_Annual_Report_2009.pdf

Al Amana Microfinance. (2010, Jauary 1). Al Amana Microfinance. Retrieved April 12, 2011, from Produits: http://www.alamana.org.ma/

Amhara Credit and Saving Institution (ACSI) . (2008, January 1). Amhara Credit and Saving Institution (ACSI) . Retrieved April 12, 2011, from Products and Services: http://www.acsi.org.et/Products\%20and\%20Services.htm

ASA. (2011, January 1). ASA. Retrieved April 12, 2011, from ASA at a Glance as of 2010: http://www.asa.org.bd/ataglance 2010.pdf

Asmitha Microfin Limited. (2004, January 1). Asmitha Microfin Limited. Retrieved April 12, 2011, from Products and Services: http://www.asmithamicrofin.com/inside/product/product.html

ASOMIF. (2011, January 1). ASOMIF. Retrieved April 16, 2011, from Educacion Financiera: $\mathrm{http} / / /$ www.asomif.org/index.php?option=com_content\&view=article\&id=59\&Itemid=30

Buro Bangladesh. (2007, January 1). Buro Bangladesh. Retrieved April 13, 2011, from About Buro: http://www.burobd.org/about.php

Badhan. (2011, January 1). Badhan. Retrieved April 13, 2011, from Products and Services: http://www.bandhanmf.com/faq.aspx\#

Banco do Nordeste. (2011, January 1). Banco do Nordeste. Retrieved April 12, 2011, from Crediamigo Produtos: http://www.bnb.gov.br/content/aplicacao/Produtos_e_Servicos/Crediamigo/gerados/produtos.asp

BRAC. (2011, January 1). BRAC. Retrieved April 13, 2011, from Microfinance: http://www.brac.net/content/microfinance

Caja Municipal Cusco. (2011, January 1). Caja Municipal Cusco. Retrieved April 13, 2011, from Productos: http://www.cmac-cusco.com.pe/

Caja Trujillo. (2011, January 1). Caja Trujillo. Retrieved April 13, 2011, from Productos: http://www.cajatrujillo.com.pe/portalnew/productos_parati_paratunegocio.html

Compartamos Banco. (2011, January 1). Compartamos Banco. Retrieved April 12, 2011, from Financial Education: http://www.compartamos.com/wps/portal/!ut/p/c1/fY5BDoIwEEXPwglm0kqLyzY2bSEp1khENqQLY2oE XBjPL8aVRPpn-fLmfhgvjG84jU84zSGO7TQsX5vcMuNJlg3eoeECnkgZU4rhzM_r_MSU7YkC1tLr9AWiuaCVcgk_7G1Pwq0t TPC04IYlcPpszbdnuKUfTmuRCz9P_tS_zkFZ6bhAohaTHa20Zk2Ru0Oi1w/dl2/d1/L2dJQSEvUUt3QS9ZQnB3LzZfUEgwOTdIRzIwR0JRRTBJOEUzNUE2Sz A2UjQ!/?mosHist=1

CRECER. (2011, January 1). CRECER Institución Financiera de Desarrollo. Retrieved April 13, 2011, from Nuestros Servicios: http://www.crecer.org.bo/index.php?mc=59

CREDIFE. (2011, January 1). CREDIFE Desarrollo Microempresarial. Retrieved April 13, 2011, from Nuestra 
Empresa: http://www.credife.com/

EKI. (2011, January 1). EKI. Retrieved April 13, 2011, from Mission and Vision: http://www.eki.ba/en/index.php?option=com_content\&view=article\&id=22\&Itemid=44

Enda Inter-Arabe. (2011, January 1). Enda Inter-Arabe. Retrieved April 13, 2011, from About Enda: http://www.endarabe.org.tn/index.php?option=com content\&view=article\&id=48\&Itemid=113\&lang=en

DBACD. (2011, January 1). Dakahlya Businessmen's Association for Community Development. Retrieved April 13, 2011, from DBACD's Range of Products: http://www.dbacd-eg.org/MFI/Products/Products.html

Dedebit Microfinance. (2011, April 13). Dedebit Microfinance. Retrieved April 13, 2011, from Operations: http://www.decsi.com.et/operations.html

Funación Mundo Mujer. (2011, January 1). Funación Mundo Mujer. Retrieved April 14, 2011, from Nuestros Servicios: http://www.fmm.org.co/index.php?section=25

Fundación Mundial de la Mujer . (2011, January 1). Fundación Mundial de la Mujer . Retrieved April 13, 2011, Productos $\mathrm{y}$ Servicios: http://www.fundaciondelamujer.com/productos servicios/productos servicios.aspx

FINCA. (2007, January 1). FINCA. Retrieved April 13, 2011, from Nuestros Productos: http://www.bancofinca.com/FINCA/nuestrosProgramas.aspx

Fondation Micro-Credit. (2009, January 1). Fondation Micro-Credit. Retrieved April 14, 2011, from Nos Produits: http://www.fbpmc.ma/\#fr_mc-profesionel

Fondep. (2011, March 9). Fondep. Retrieved April 14, 2011, from Home: http://www.fondep.com/ang/default.htm

Fondi Besa. (2008, January 1). Fundi Besa. Retrieved April 13, 2011, from Mission: http://www.fondibesa.com/en/index.html

Grameen Bank. (2011, January 11). Grameen Bank. Retrieved April 14, 2011, from About Us: http://www.grameen-info.org/index.php?option=com_content\&task=view\&id=792\&Itemid=759

Grameen Koota. (2009, January 1). Grameen Koota. Retrieved April 14, 2011, from New Initiatives: http://www.gfspl.in/Beyond Credit.html

INECOBANK. (2011, February 18). INECOBANK. Retrieved April 14, 2011, from About Us: http://www.inecobank.am/index.php?page=about

Integrated Development Foundation. (2011, January 1). Integrated Development Foundation. Retrieved April 14, 2011, from Programs: http://www.idfbd.org/program products.htm

Kazakhstan Loan Fund. (2006, Jaunary 1). Kazakhstan Loan Fund. Retrieved April 14, 2011, from Produkt: http://www.kclf.kz/eng/viewpage.php?page_id=21

Kashf Foundation. (2007, January 1). Kahsf Foundation. Retrieved April 14, 2011, from Products and Services: http://www.kashf.org/site files/products.asp

Khan Bank. (2010, January 1). Khan Bank. Retrieved April 13, 2011, from Abou Us: http://www.khanbank.com/en/35/About-Us.html

Madura Microfinance Ltd. (2011, January 1). Madura Microfinance Ltd. Retrieved April 16, 2011, from Microeducation: http://www.maduramicrofinance.com/app microeducation.html

Microcredit Organization Sunrise. (2005, January 1). Microcredit Organization Sunrise. Retrieved April 14, 2011, from Credit Products: Microcredit Organization Sunrise

MIKROFIN Banja Luka. (2009, January 1). MIKROFIN Banja Luka. Retrieved April 14, 2011, from Proizvodi i usluge: http://www.mikrofin.com/index.aspx

Partner. (2011, January 1). Partner. Retrieved April 14, 2011, from Home: http://www.partner.ba/index.php/en/home.html

Programas para la Mujer . (2007, January 1). Programas para la Mujer - Peru. Retrieved April 14, 2011, from Integrated Services: https://promujer.org/index.tpl?\&ng_view=33

Saadhana Microfin Society. (2005, January 1). Saadhana Microfin Society. Retrieved April 14, 2011, from Methodology: http://www.saadhana.org/Identification\%200f\%20Potential\%20Area.html\#IGO

Sanasa Development Bank. (2011, January 1). Sanasa Development Bank. Retrieved Janaury 1, 2011, from Community: http://www.sdb.lk/com c.asp

Shakti Foundation for Disadvantaged Women. (2011, January 1). Shakti Foundation for Disadvantaged Women. Retrieved April 15, 2011, from Programs: http://www.sfdw.org/index.php?option=com_content\&view=category\&layout=blog\&id=42\&Itemid=2

Sharada's Women's Association for Weaker Section. (2008, January 1). Sharada's Women's Association for Weaker Section. Retrieved April 15, 2011, from Methodology: http://www.sccimicrofinance.com/methodology2.php

SKS Microfinance Private Limited. (2009, January 1). SKS Microfinance Private Limited. Retrieved April 15, 2011, from Ultra Poor Programme: http://www.sksindia.com/ultrapoor_programme.php

Reyada Development and Employment Fund. (2010, January 1). Reyada Development and Employment Fund. Retrieved April 13, 2011, from Administration Development and Training: 
http://www.defjo.com/site/en/2010-09-01-11-58-46/2010-09-01-12-00-03/2010-09-01-12-25-44Zakoura Micro-Credit. (2005, January 1). Zakoura Micro-Credit. Retrieved April 14, 2011, from Produits: http://www.zakourafondation.org/rubrique.php3?id_rubrique=2\&id_parent=2\&ordre_menu=1

WWB. (2011, January 1). WWB. Retrieved April 14, 2011, from Productos y Servicios: http://www.fwwbcol.org/index.php?option=com_content\&view=article\&id=112\&Itemid=22

\section{Appendix 3: Financial Education - Findings of the web-based research} Figure A1 Banco Compartamos, S.A.

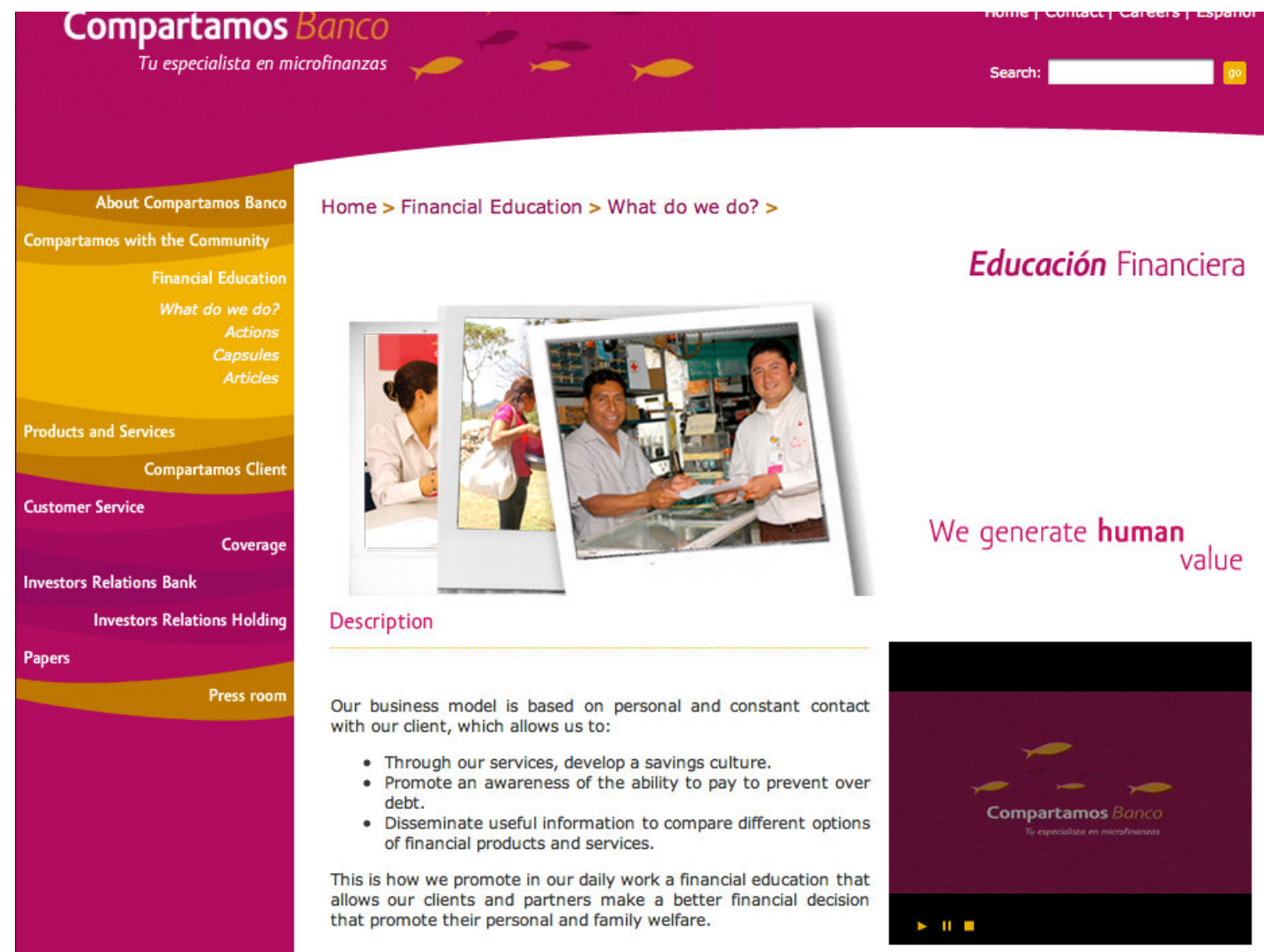

Source:http://www.compartamos.com/wps/portal/!ut/p/c1/04_SB8K8xLLM9MSSzPy8xBz9CP0os_gADwNLcw93 IwN3p0BXA08LV2NTRzNvA7MgU6B8JG55J3MCusNB9uHẌjyLvHruYmBk7OgUZORlauxtbAaRN8ABHA30 Tz yclPlglPz9AtyIwwyA9IVAdx3vkg!/dl2/d1/L2dJQSEvUUt3QS9ZQnB3LzZfUEgwOTdIRzIwROJRRTBJOEUzNU E2SzA2UjQ!/?mosHist=1 
Figure A2 Bangladesh RuRal AdVAnCEMEnT Commitee (BRAC) $\begin{array}{ll}\square \text { Asla } & \text { Bangladesh: Education: Social and Financial } \\ \square \text { Bangladesh } & \text { Empowerment of Adolescents }\end{array}$ $\Phi$ Health

E Education

Primary Schools Pre-primary Schools Inclusivenes: Support to Formal School Suppon to Formal Schod Adolescent Development Social and Financial Empowerment of Adolescents Multi-purpose Community Learnin Imoroving Performance \& Learning Scholarship Programme (Medhabikash)

17 Agriculture \& Food Secunity Community Empowerment \& + Community Empowerment \&. Environment

Gender Justice \& Diversity

(t) Legal Empowerment Social Enterprises Socially Responsible Investments Targeting Extreme Poverty

Tlargeting Extreme Poverty

$\mp$ Social Communication \& Advocacy 田 Training Division Afghanistan 田 Pakistan Af Africa

Americas

A Americas

Technical Assistance Outreach

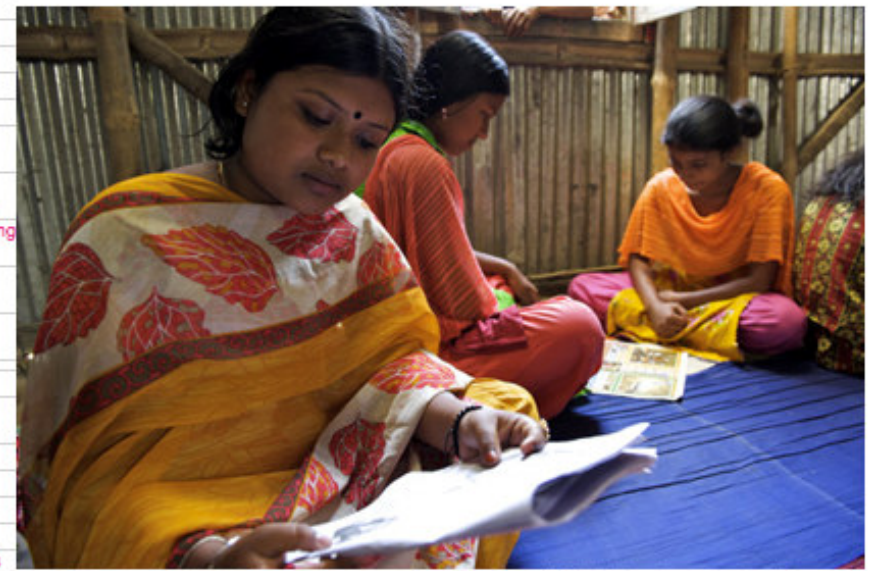

The Social and Financial Empowerment of Adolescents (SOFEA) project is a BRAC initiative aimed at providing adolescent girls with financial and social support to enable empower themselves.

The SOFEA programme comprises of the following vital components:

- A secure place for adolescent girls to socialise

Life-skills training

- Livelinood training

- Savings and credit facilities

- Savings and credit faciltes

The components complement each other and create the complete support structure needed by an adolescent girl. The secure place provides a much-needed socialisation space, creating social cohesion. Life skills training raises girls' level of social awareness, allowing them to make informed decisions. Livelihood training equips girls with the skills they need to engage in income generating activities, starting them off on the path towards financial independence. The financial literacy course provides insight into the financial aspects of managing a small business. The credit and savings facilties are a source for seed capital for the girls to start small businesses.

To garner support from their families and the community, the programme engages in community sensitisation to ensure that even after BRAC leaves, these girls will continue enjoying their rights, as well as receive the attention and support that they deserve from their family and community.

The project aims at empowering girls to make more informed decisions about issues that affect their lives. Over time, these girls become more confident and independent through social and financial empowerment. By educating them, the girls will lead a healthy life, and be informed mothers, bringing up healthy families in the future.

Source:http://www.brac.net/content/bangladesh-education-social-and-financial-empowerment-adolescents 
Figure A3 CRÉdito CON EduCACIÓN RURAL (CRECER)

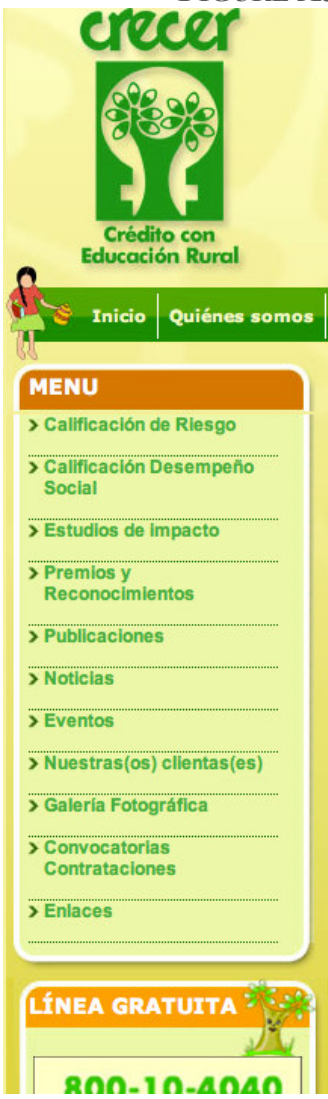

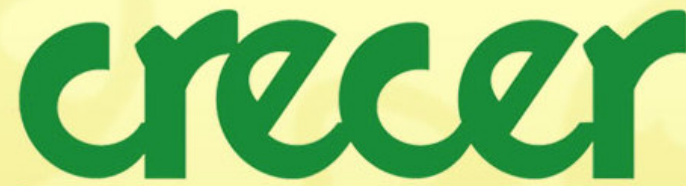

Institución Financiera de Desarrollo

\section{Educativos}

\section{Servicios Educativos}

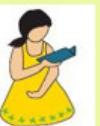

El objetivo principal de CRECER es proporcionar servicios financieros y educativos integrados, con el fin de apoyar el mejoramiento de la calidad de vida de las socias, en especial de las que pertenecen a sectores vulnerables.

El componente de educación en la Banca Comunal está basado en la educación activa/participativa para adultos que busca afianzar las prácticas adecuadas que mejoren la calidad de vida de las mujeres y sus familias.

El proceso educativo se realiza, con carácter obligatorio, en las reuniones quincenales o mensuales de acuerdo al ciclo crediticio. Cada sesión educativa -que además cuenta con un importante material educativo de apoyo- tiene una duración aproximada de 30 minutos, es impartida por el (la) asesor(a) de crédito y educación quien logra establecer una relación de confianza entre las clientas y la institución.

De este modo, CRECER usa el estimulo del préstamo para impartir conocimientos sobre cuatro grandes áreas temáticas:

\section{Salud Integral}

Lo que buscamos con el módulo de Salud integral es lograr que las socias compartan, amplien y apliquen conocimientos y prácticas básicas de prevención y cuidados esenciales de salud integral.

Source: http://www.crecer.org.bo/index.php? $m c=7$

Figure A4 Fundacion para la Promocion y el Desarrollo (ASMOIF)

\begin{tabular}{|l|}
\hline $\begin{array}{c}\text { Escuchar tus rodamos pora } \\
\text { mojorar nuostro oloncion }\end{array}$ \\
\hline Llam anos es GRATISII \\
\hline
\end{tabular}

Pero además permite proveer educación sobre más de 50 temas distintos, relativos a la salud integral de la mujer, del niño(a) y de toda la familia; esta importante cantidad de contenidos nos da el liderazgo en este tipo de servicios.

Entre los temas que desarrollamos en esta área están: la Salud Sexual y Reproductiva, la Salud Materna, la Salud Infantil, la Prevención de Enfermedades Infecciosas, el Alcoholismo y la Salud Ambiental, entre otros.

\section{Derechos Ciudadanos}

Este módulo tiene como propósito lograr que nuestras socias ejerzan sus derechos y obligaciones fundamentales; pero además, las impulsa a asumir cambios de actitud personal, autovaloración y liderazgo, generando un importante cambio cualitativo en sus vidas.

Gracias al apoyo que presta CRECER se ha desencadenado un crecimiento emocional en las socias, razón por la cual requieren capacitación, por ejemplo, en técnicas de negociación.

\section{Negocios y Educación Financiera}

El conocimiento de este módulo les permite a nuestras socias ampliar y fortalecer sus habilidades $y$ destrezas empresariales, pero además sistematizar sus conocimientos $y$ prácticas previas.

También se generan procesos de aprendizaje con los cuales nuestras clientas podrán mejorar sus habilidades en el manejo del dinero, la dirección de sus negocios, la atención al cliente y, por ende, a controlar mejor el incremento de sus ventas.

Se estudia, al mismo tiempo, la elaboración y el cumplimiento de un presupuesto, y la planificación y el uso de los servicios bancarios.

\section{Gestión y Manejo de Banca Comunal}

Este módulo, de carácter transversal, tiene como objetivo principal capacitar a mujeres líderes que forman parte de la mesa directiva de sus Asociaciones en "Gestión las Asociaciones Comunales".

Los contenidos están orientados a capacitar en las responsabilidades y roles que tiene cada socia dentro de la asociación, pero además sobre negociación, cumplimiento del reglamento de la banca comunal, manejo de la mora, conocimiento de las personas idóneas para formar parte de las asociaciones, etc. 


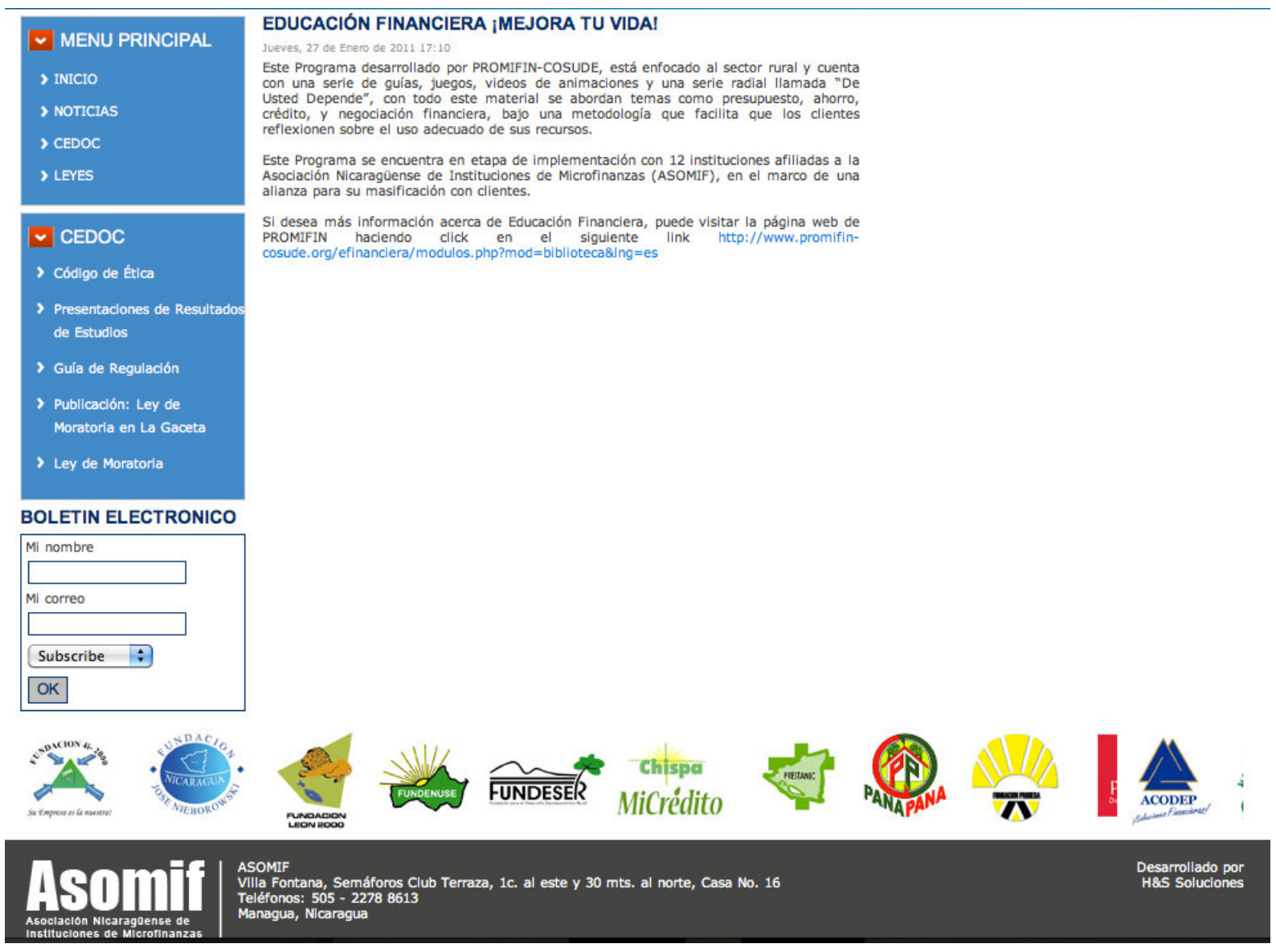

Source:http://www.asomif.org/index.php?option $=$ com_content\&view $=$ article\&id $=73 \& I t e m i d=45$ 